\title{
Assessment of aquifer zones and its protection via second-order geoelectric indices in parts of drought-prone region of Deccan Volcanic Province, Maharashtra, India
}

\author{
G Shailaja, G Gupta*, N Suneetha and M Laxminarayana \\ Indian Institute of Geomagnetism, New Panvel (W), Navi Mumbai 410 218, India. \\ *Corresponding author.e-mail: ggupta@iigs.iigm.res.in gupta_gautam1966@yahoo.co.in
}

MS received 30 July 2017; revised 26 June 2018; accepted 14 August 2018; published online 20 March 2019

Assessment of aquifer protection was studied in the drought-prone regions of Mann Ganga River basin encompassing the districts of Satara, Sangli and Solapur, in Deccan Volcanic Province of Maharashtra, India, using electrical resistivity technique. The study was also aimed at alleviating the drinking water scarcity in these regions. A total of 118 vertical electrical sounding sites were occupied using Schlumberger electrode configuration and the data analysis revealed two to five layered curve types. The modelled layer resistivity and layer thickness at every station were used to calculate the Dar-Zarrouk parameters (i.e., longitudinal conductance $S$ and transverse resistance $T$ ). The $S$ values showed that $67 \%$ of the area had a poor aquifer protection, whereas $16 \%$ had moderate protective capacity and $13 \%$ had weak aquifer protective capacity rating. Only $4 \%$ of the study area depicted a good protective capacity rating. This indicates that the study area has a rather poor aquifer protective capacity rating, and thereby more prone to infiltrating contaminants. The regions with good-to-moderate protective capacity are envisaged to be potential groundwater zones. The large variation in electrical anisotropy $\lambda$ ranging from 1 to 2.8 in the study area suggests the anisotropic disposition of the aquifers in basaltic region. The intersection points of several lineaments in the study area are probable to be the most favourable zone for groundwater recharge. This is corroborated by the lineament density of the area, wherein high lineament density reflects high probability of groundwater infiltration. Moreover, the rainfall distribution suggests that the central and eastern parts of the study area receive maximum precipitation, which also coincides with the zones of high lineament density. Particle size analysis was determined from 92 soil samples in the study area and correlated with the longitudinal conductance in order to identify the sub-surface conditions and the aquifer vulnerability. Significant positive correlation was observed between the longitudinal conductance and percentage of clay fraction in the study area. These results could be relied upon for making preliminary estimates of protection from pollution for a sustainable groundwater development and management in future.

Keywords. Electrical resistivity; Mann Ganga River basin; longitudinal conductance; protective capacity; Deccan Volcanic Province.

\section{Introduction}

Groundwater is a major source for drinking, domestic needs, industrial and agricultural activities, and thus, its exploration assumes a great implication for the society. However, in today's technologically advanced world, the biggest crisis that human beings facing is water scarcity. This is 
more severe in the hard rock and drought-prone regions around the globe. This grave situation is due to rising demands of increasing population, over extraction of easily available surface and groundwater resources, increasing human impact on the environment and contamination of available water sources and changing climate, to name a few.

It is a well-established fact that there is relentless scarcity of groundwater in hard rock terrains. The fracturing, faulting, etc. within these hard rock trap limited the amount of groundwater. Some districts of Maharashtra in the hard rock Deccan Volcanic Province (DVP) are no exception to groundwater paucity. However, not much information is available on the lineaments, conduits, joints and fractures in the hydrogeological setup as well as their role in the incidence and movement of groundwater in the semiarid regions of DVP, Maharashtra. Several regions in these districts fall in the rain shadow zone of the Western Ghats. Therefore, an urgent needed for locating the auxiliary sources of groundwater is felt almost all over the region. Hydrogeological mapping can be integrated with geophysical data fruitfully to effectively plan the location of such facilities.

Geophysical investigations are being successfully carried out worldwide for delineating groundwater resources. Electrical resistivity technique is the most popular among all non-invasive geophysical methods due to its relative ease to acquire data, inexpensive instruments, widely available interpretational schemes and relationship between electrical properties, geologic formations and demarcation of aquifers (Zohdy and Jackson 1969; Kotra et al. 2016). To this effect, numerous researchers have extensively used electrical resistivity technique for a variety of problems such as groundwater chemistry of hard rocks (Ramesh and Elango 2012; Mondal et al. 2016), saline water intrusion issues (Maiti et al. 2013; Ali Kaya et al. 2015), geothermal explorations (Kumar et al. 2011), environmental assessment (Gómez-Puentes et al. 2016) and geotechnical investigation (Adejumo et al. 2015).

The demand for water in the drought-prone regions of Maharashtra has been increasing due to the immense requirement for domestic and agricultural uses, which is further aggravated owing to the paucity of rainfall. Therefore, during the summer months, all the wells go dry and it is seemingly difficult to manage with the existing water supplies. Therefore, to overcome this problem, effective ways of harnessing the groundwater resources are imperative.
During monsoon period, some of the rainwater flows into rivers, lakes and rivulets, whereas some descends into the bowels of the earth's surface due to gravitational effect, passing between soil particles and other rock formation until it reaches the aquifer. However, the rate of groundwater flow depends on the pore spaces and its interconnectivity in the soil. As water percolates through different subsurface layers into the aquifer, it gets filtered; however, there is a thick chance of contaminants being infiltrated beneath. During the course of filtration, the rock matrix acts as sieves, thereby reducing the flow rates as water finds its way through the small pore spaces resulting in long residence time. Vulnerability of an aquifer is related to its ability to resist anthropogenic and natural perturbation, and therefore, it is vital to comprehend the aquifer characteristics. It is reported that residence time of infiltrating water in aquifers with large pore spaces is shorter than that for smaller pore spaces, and consequently, water moves rapidly leading to poor natural filtration process. In such case, it is hard to assuage contaminants by natural filtration. Clay particles overlying an aquifer are protective layers that can offer natural protection to the aquifer from contaminants (Shevnin et al. 2007). The parent rock gets altered into discrete soil particles of varied shapes and sizes due to intense weathering. The disintegrated rocks and weathered regolith materials generally have a wide range of particle size. Soil texture, which is the relative proportions of clay, silt and sand contents, is one of the most vital properties for characterising the soil. The physical and chemical behaviours of soil bear a considerable influence on soil texture with respect to water content and its movement. This parameter not only affects the porosity of soil but also affects soil erosion. Therefore, particle size analysis (PSA) of soils is critical for determining the fitness of soils in terms of protection against contamination and hydrogeological analysis.

Bearing this in mind, proper identification of soil characteristics is also vital as it influences the quality of surface and groundwater, especially in arid and semiarid regions (Engelman and Leroy 1993; Lal and Stewart 1994). Several investigators have applied the combination of electrical resistivity method with water chemistry to decipher the aquifer parameters and quality of water (Mondal et al. 2013; Rajesh et al. 2015; Batayneh and Al-Taani 2016; and references therein). Few researchers have attempted to evaluate the groundwater potential zones, its contamination and 


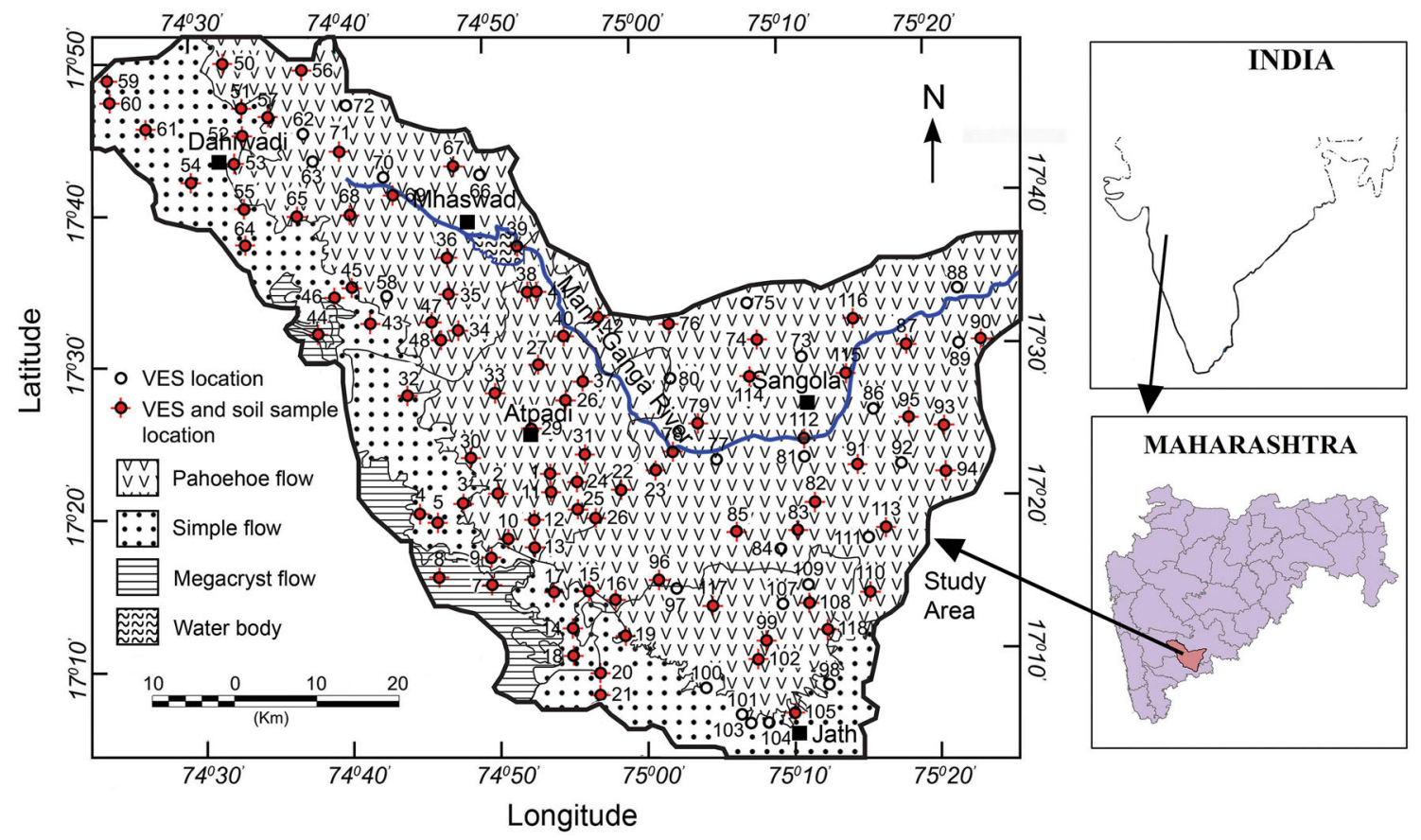

Figure 1. Geological map of the Mann Ganga River basin in Maharashtra. The VES points and soil sampling locations are also shown.

fertility prospects of soils using PSA and metal contents in soils (Inakwu et al. 2003; Skordas and Kelepertsis 2005; Deshmukh and Aher 2014; Machender et al. 2014). However, very limited literature exists (Delgado-Rodríguez et al. 2011; Islami et al. 2012; Dolui et al. 2016; Kotra et al. 2016), wherein the resistivity data are integrated with physicochemical characteristics of soil with a view to provide information on the subsurface layers and characterisation of the aquifer system and associated vulnerability, if any. The primary objective of the present work is three-fold: (i) to define the aquifer zones within the weathered/fractured basaltic rocks as well as below the traps in the Mann Ganga River basin for groundwater investigation, (ii) to estimate the secondary geophysical indices [Dar-Zarrouk (D-Z) parameters] using vertical electrical sounding (VES) data for assessing the protective capacity of the aquifers and (iii) to establish a qualitative relationship between longitudinal conductance and the soil particle size distribution in the study area. This study, first of its kind in drought-prone region of DVP, Maharashtra, is expected to be a pre-requisite for the delineation of aquifers obscured within and below the Deccan traps and assessment of groundwater potential and its protection ability in the region of interest.

\section{Geology and hydrogeology of the study area}

The study area is located in the southeastern part of Maharashtra in Satara, Sangli, and Solapur districts. This region, characterised by Mann Ganga River basin, extends from $17^{\circ} 00^{\prime} 00^{\prime \prime}-17^{\circ} 50^{\prime} 30^{\prime \prime} \mathrm{N}$ latitudes to $74^{\circ} 20^{\prime} 00^{\prime \prime}-75^{\circ} 30^{\prime} 00^{\prime \prime} \mathrm{E}$ longitudes. The geological map of the study area is shown in figure 1. The VES and soil sample location points are also marked in figure 1 . The total area of the Mann Ganga River basin is $4753.258 \mathrm{~km}^{2}$. The maximum elevation of $980 \mathrm{~m}$ is observed in the western and northwestern parts of the basin, whereas the minimum elevation is $354 \mathrm{~m}$ above mean sea level in the northeastern part. The study area is located on the leeward side of Western Ghats, characterised by the rain shadow zone. The rainfall here is below normal and therefore is a drought-prone region. The average annual rainfall in the Mann Ganga River basin computed during 2001-2015 is about $500 \mathrm{~mm}$.

The entire study area is underlain by Deccan trap basaltic lava flows of upper Cretaceous to lower Eocene age and occupies about 95\% of the total study expanse (figure 1). Figure 2 illustrates the general cross-section of hydrogeology in the study area. The flows are represented 


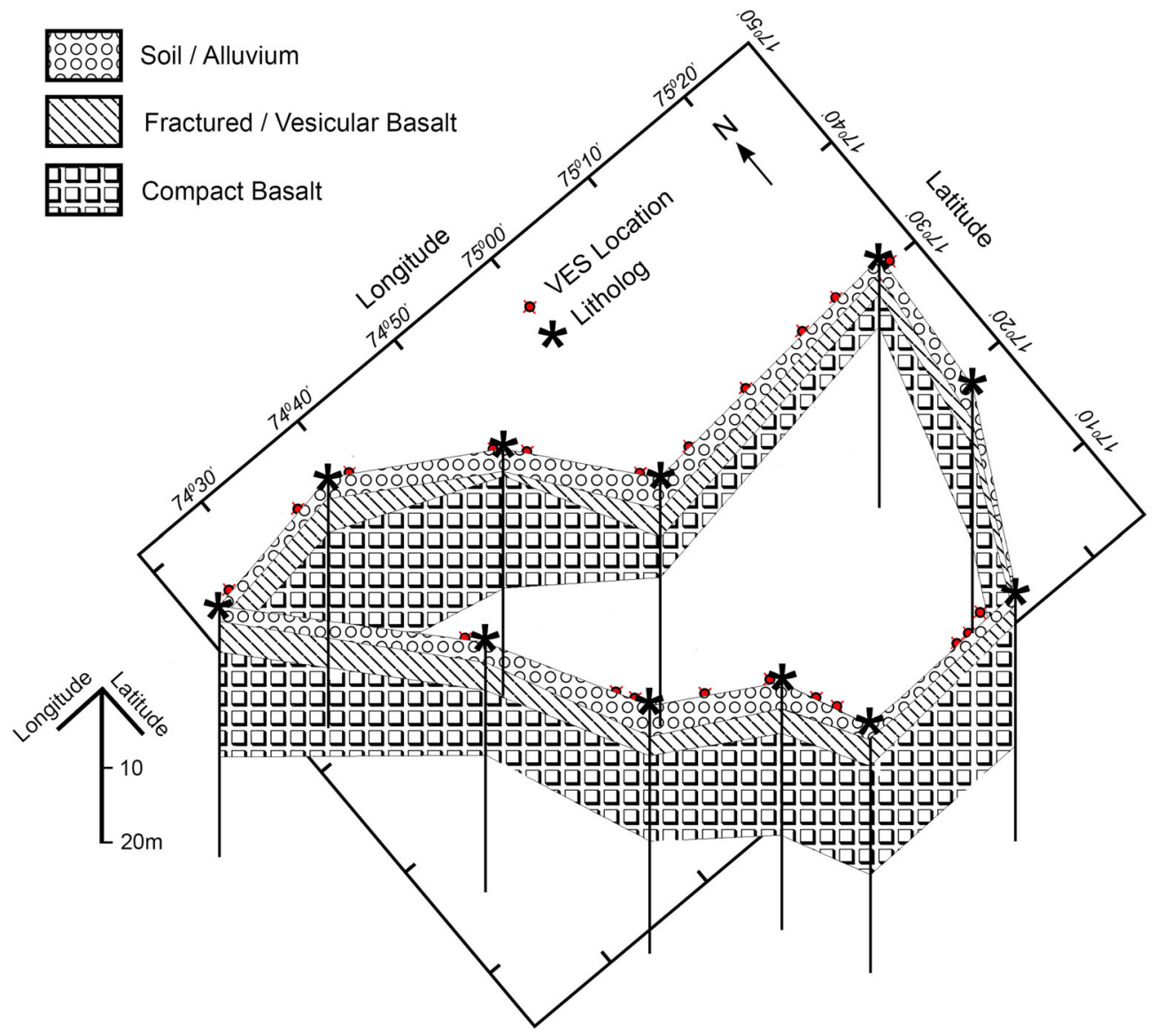

Figure 2. General cross-sectional hydro-geological map of the study area.

by compact and massive basalt at bottom and fractured/vesicular portion at top and are separated from each other by thin bole bed. Physiographically, the study area can be broadly divided in four major units, namely (i) hills and Ghats, (ii) foothill zones, (iii) plateaus and (iv) plains. Mann is the major river in the area. The drainage pattern is parallel to semi-dendritic and the drainage density is quite high. The shallow alluvial formation of recent age occurs as narrow stretch along the Mann Ganga River with limited areal extension.

The groundwater occurs under phreatic, unconfined, semi-confined and confined conditions. Generally, the shallower zones down to depth of $20 \mathrm{~m}$ below ground level ( $\mathrm{m} \mathrm{bgl}$ ) form phreatic aquifer. The water-bearing zones occurring between the depth of 20 and $40 \mathrm{~m}$ are weathered and have water under unconfined or semi-confined condition. Deep confined aquifers occur below the depth of $40 \mathrm{~m}$ and beyond (CGWB 2013). The fractured and vesicular thickness of different lava flows varies from 8 to $10 \mathrm{~m}$ and forms the potential aquifer zones. However, the nature and density of vesicles and their distribution, interconnection, depth of weathering and topography of the area are the important factors for occurrence and movement of groundwater in vesicular unit. It can be seen from figure 1 that almost the entire study area is covered by pahoehoe type flows. This type of flow is reported to be more permeable than the simple type flow (Davis and DeWiest 1966). The massive sections of basaltic lava flows are hard and compact and as such are devoid of primary porosity and permeability; however, the processes of weathering and presence of joints and fractures have developed secondary porosity and permeability (Deolankar 1980).

The yield of dug wells varies between 10 and $190 \mathrm{~m}^{3}$ /day in winter season, whereas in summer, it varies between 5 and $20 \mathrm{~m}^{3} /$ day. The discharge values of both shallow and deeper aquifer range up to $15 \mathrm{l}$ per second as observed from exploration wells in the study area (CGWB 2013). These disparities can be attributed to the hydraulic and morphologic characteristics of the tributaries of 
Mann Ganga River. The depth to water level is in the range of $5-20 \mathrm{~m} \mathrm{bgl}$ in pre-monsoon season, whereas it is about $5-10 \mathrm{~m} \mathrm{bgl}$ during postmonsoon (CGWB 2013).

\section{Survey design and data treatment}

A total of 118 VES were carried out within the Mann Ganga River basin (figure 1), adopting Schlumberger electrode configuration with a halfelectrode separation of $100 \mathrm{~m}$, using IGIS (Hyderabad) made SSR-MP-AT resistivity meter. The depth of penetration is proportional to the separation between the current electrodes and provides information on the stratification of the ground (Dahlin 2000).

The preliminary construal of VES data was accomplished using the conventional partial curve matching technique with two-layer master curves in combination with auxiliary point diagrams (Orellana and Mooney 1966). The layer resistivities $\rho$ and thickness $h$, thus obtained, are served as the initial parameters for computer-aided interpretation using IPI2WIN software, version 3.0.1, a7.01.03 (Bobachev 2003) for interactive semiautomated interpretation. All the sounding curves suggest 2-5 layered structures (see table A1 in the Appendix).

However, there is always an overlapping of resistivity values in certain geomaterials (e.g., clay, water, shale, etc.) (Telford et al. 1990; Bhattacharya and Shalivahan 2016), and to minimise the effects of these geophysical similarities in subsurface lithology, secondary geophysical indices, also known as the D-Z parameters (Maillet 1947), are used. The significance of using secondary geophysical parameters is that the contour pattern and boundaries will be distinct, clear and will not display an overlapping character thus reducing the uncertainty in interpretation.

First-order geoelectric parameters $(\rho$ and $h)$ derived were utilised in obtaining $\mathrm{D}-\mathrm{Z}$ parameters (table A1). The secondary geophysical parameters of significance in this study are longitudinal conductance $(S)$, transverse resistance $(T)$ and electrical anisotropy $(\lambda)$, which are given by Zohdy et al. (1974) for $n$-layer as:

Longitudinal conductance,

$$
S=\sum_{i=1}^{n}\left(h_{i} / \rho_{i}\right),
$$

Transverse resistance,

$$
T=\sum_{i=1}^{n}\left(h_{i} \rho_{i}\right),
$$

where $h_{i}$ is the saturated thickness of each layer and $\rho_{i}$ is the true resistivity of each layer.

Coefficient of anisotropy,

$$
\lambda=\sqrt{\left(\frac{\rho_{t}}{\rho_{l}}\right)},
$$

where $\rho_{t}$ and $\rho_{l}$ are the average transverse resistivity and average longitudinal resistivity, respectively.

Higher $S$ values generally indicate a relatively thick succession of overburden and is given the highest priority in terms of evaluation of groundwater potential. The $S$ values are also used in evaluating the protective capacity of the aquifer. Henriet (1976) suggested that the earth medium act as a natural filter to the infiltrating fluid and that its ability to hinder fluid is a measure of its protective capacity. Furthermore, the combination of layer resistivity and thickness in the $\mathrm{D}-\mathrm{Z}$ parameters $(S$ and $T$ ) may be of direct use in aquifer protection studies to signify the percolation of contaminants into the aquifer and for the evaluation of hydrologic properties of aquifer (Shailaja et al. 2016). The protective capacity is considered to be proportional to the longitudinal unit conductance $(S)$. Accordingly, the overburden protective capacity was evaluated using the total longitudinal unit conductance $(S)$ values.

Soils samples were collected from 92 sites corresponding to VES locations (figure 1) from 15 to $20 \mathrm{~cm}$ depths (the depth of tillage or to the effective rooting depth of plants). Several systems of size classification are used to classify the limits and ranges of soil particle size. In this study, the US Department of Agriculture (USDA) system of classification (Soil Survey Staff 1975) has been used to define the size of the particles. The PSA was evaluated at the Environmental Magnetism Laboratory, IIG, New Panvel.

Soil samples were air dried for several days at room temperature in the laboratory and sieved through $0.25 \mathrm{~mm}$ for soil analysis, making sure that no aggregates are retained in the sieve. PSA was performed using a CILAS 1064 laser granulometer with a detection range from 0.03 to $500 \mu \mathrm{m}$. About $200 \mathrm{mg}$ of soil samples was dispersed in sodium 


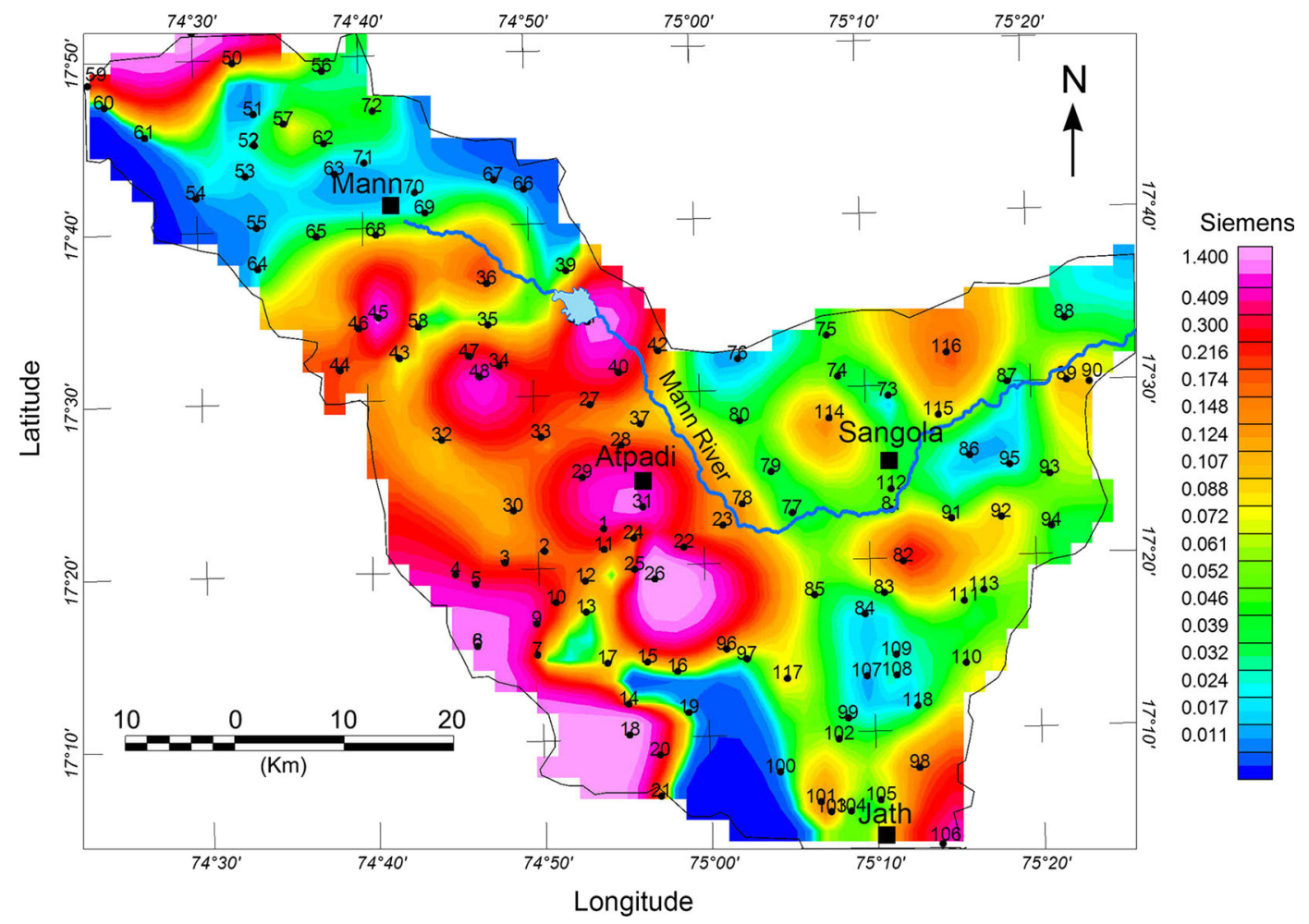

Figure 3. Spatial distribution of longitudinal conductance $(S)$ in the study area.

hexametaphosphate $\left[\mathrm{Na}\left(\mathrm{PO}_{3}\right)_{6}\right]$ solution and was exposed to ultrasonic treatment for $5 \mathrm{~min}$ for a proper disaggregation and dispersion of the soil particles. Later, the ultrasonic-treated soil sample is poured to the sample chamber and laser analysed for the grain size spectrum for a 10-min programme. For data reproducibility, three runs per sample were conducted. Finally, a soil textural triangle was used to determine soil textural class from the percentages of sand, silt and clay in the soil. In the present study, the particle size characteristics of soils are discussed in relation with geophysical indices (longitudinal conductance $S$ ) and their effect on protective capacity of aquifers. Depending on the size distribution, primary particles $(<2 \mathrm{~mm})$ are usually divided into three classes, e.g., sand, silt and clay.

\section{Results and discussion}

\subsection{Estimation of $D-Z$ and other parameters}

As stated earlier, a total of 118 VES were carried out via Schlumberger configuration in the drought-prone, hard-rock terrain of DVP encompassing Mann-Sangola-Jath-Atpadi subdivisions of Satara, Solapur and Sangli districts of
Maharashtra (figure 1). The D-Z parameters were calculated to estimate the protective capacity of the underlying aquifers from infiltrating contaminants, which will provide a perception of the spatial variation of these parameters to demarcate the fresh water bodies and to delineate the groundwater potential zones.

The longitudinal conductance $(S)$ value estimated from equation (1) varies from a minimum of $0.0023 \mathrm{~S}$ to a maximum of $1.605 \mathrm{~S}$ (figure 3 ). The spatial variation map further depicts that the eastern, southern and northwestern parts are infested with low $S$ values $(0.0023-0.05 \mathrm{~S})$. The central and western parts are characterised by relatively high $S$ values greater than $0.1 \mathrm{~S}$.

According to Oladapo and Akintorinwa (2007), clayey overburden is characterised by reasonably high longitudinal conductance and offers protection to the underlying aquifer from contaminants to permeate. The modified classification of aquifer protective capacity rating (Oladapo et al. 2004) facilitates to categorise an area into poor, weak, moderate, good, very good and excellent protective capacity zones (table 1).

The longitudinal conductance map (figure 3) suggests that the protective capacity rating over the entire basin is about $67 \%$, which is rather poor. About $4 \%$ of the area falls within the good 
protective capacity, whereas about $16 \%$ represents moderate protective capacity rating and the remaining $13 \%$ exhibits weak protective capacity. This implies the fact that major part of the study area, which is characterised by relatively poor-toweak capacity rating, is more prone to percolating contaminants. These results further suggest that the areas with moderate-to-good aquifer protective capacity correspond with zones of significant clayey overburden, which are sufficient enough to protect the aquifer from contamination.

The total transverse resistance $(T)$ calculated from equation (2) varies from 106 to $104,951 \Omega \mathrm{m}^{2}$ in the study area (figure 4). It is quite evident that high $T$ values $\left(>4000 \Omega \mathrm{m}^{2}\right)$ represent the fresh water regime. The parts of central, eastern,

Table 1. Modified protective capacity rating (after Oladapo et al. 2004).

\begin{tabular}{ll}
\hline $\begin{array}{l}\text { Longitudinal } \\
\text { conductance }(S)\end{array}$ & $\begin{array}{c}\text { Protective } \\
\text { capacity rating }\end{array}$ \\
\hline$>10$ & Excellent \\
$5-10$ & Very good \\
$0.7-4.9$ & Good \\
$0.2-0.69$ & Moderate \\
$0.1-0.19$ & Weak \\
$<0.1$ & Poor \\
\hline
\end{tabular}

southern and northwestern sectors of the study area (figure 4) signify fresh water zones. These areas are also depicted with low $S$ values. Higher $T$ values usually reflect high transmissivity and thus, highly porous to fluid movement. Hence, there is a possibility of enhanced passage of contaminants into the groundwater (Tsepav et al. 2015). The southwestern and central parts of the study area are characterised by low $T$ values $\left(<4000 \Omega \mathrm{m}^{2}\right)$.

The resistivity of a layer depends more on the saturation of the layers and not necessarily on the thickness of the aquifer; hence, higher resistivity may not correlate with areas with thicker aquifer. Aquifer resistivity varies from 10 to $9385 \Omega \mathrm{m}$ in the study area (figure 5). The central part and the pockets of western sector of the study area are characterised by low aquifer resistivity values (10-60 $\Omega \mathrm{m})$, signifying that it has a good groundwater potential. However, the northern, northeastern and southern parts divulge high values of aquifer resistivity.

The highly thick aquifers possess higher groundwater potential. The variation in aquifer thickness in this region (figure 6) can be ascribed to topography and geological structure. The aquifer thickness values vary from a minimum of $0.336 \mathrm{~m}$ to a maximum of $75.7 \mathrm{~m}$. The spatial variation of aquifer thickness suggests that the western part,

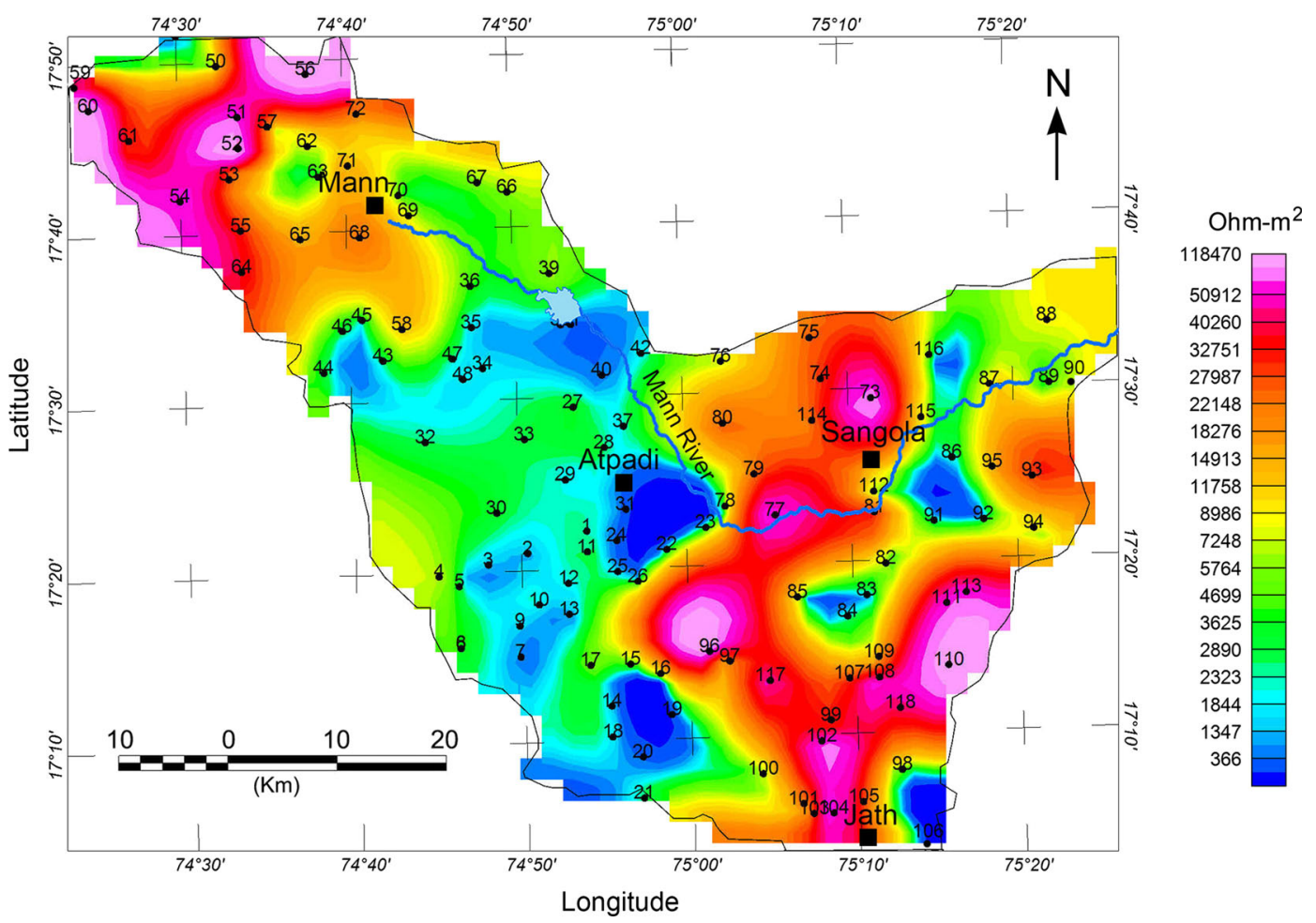

Figure 4. Spatial distribution of transverse resistance $(T)$ in the study area. 


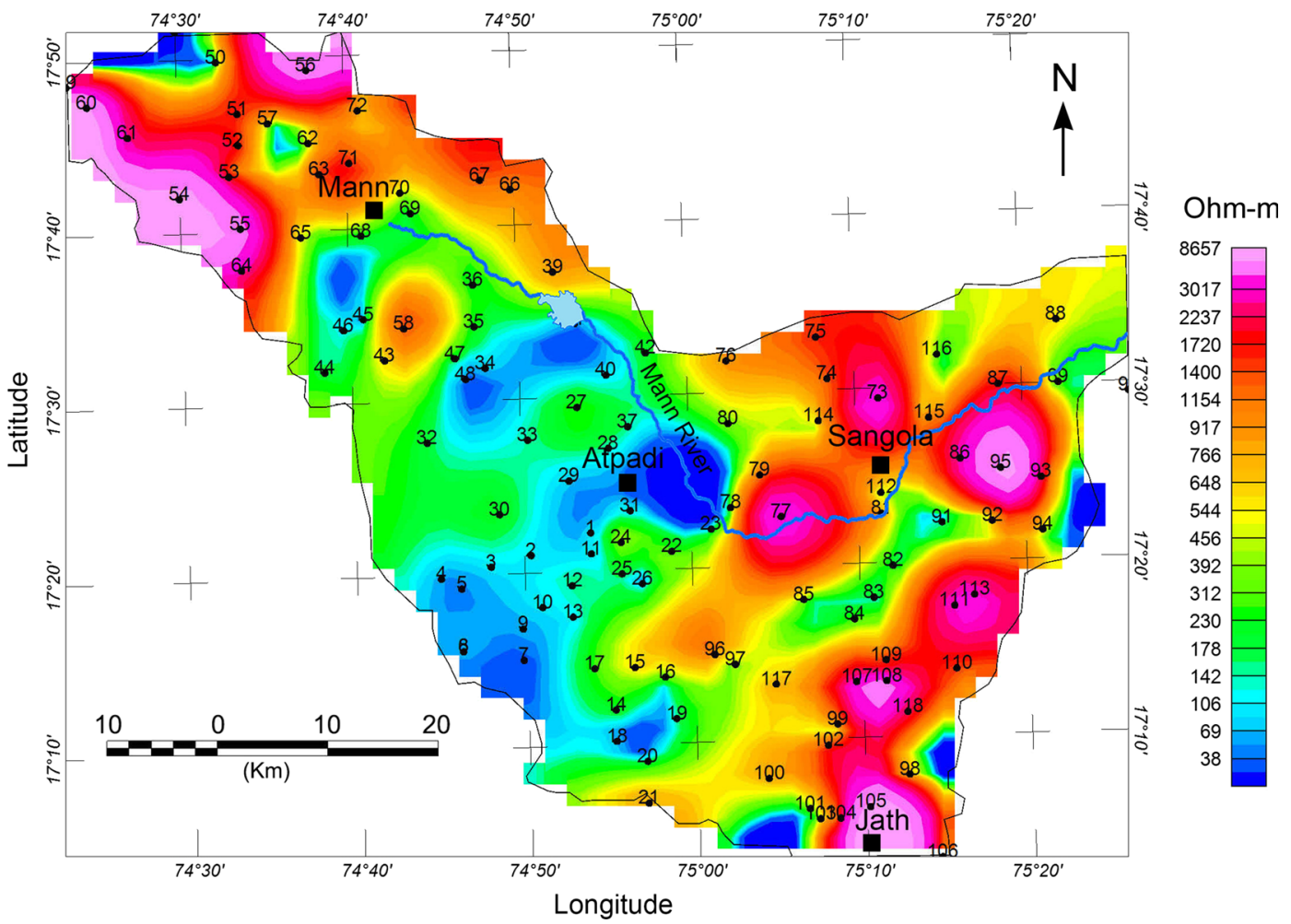

Figure 5. Spatial distribution of aquifer resistivity in the study area.

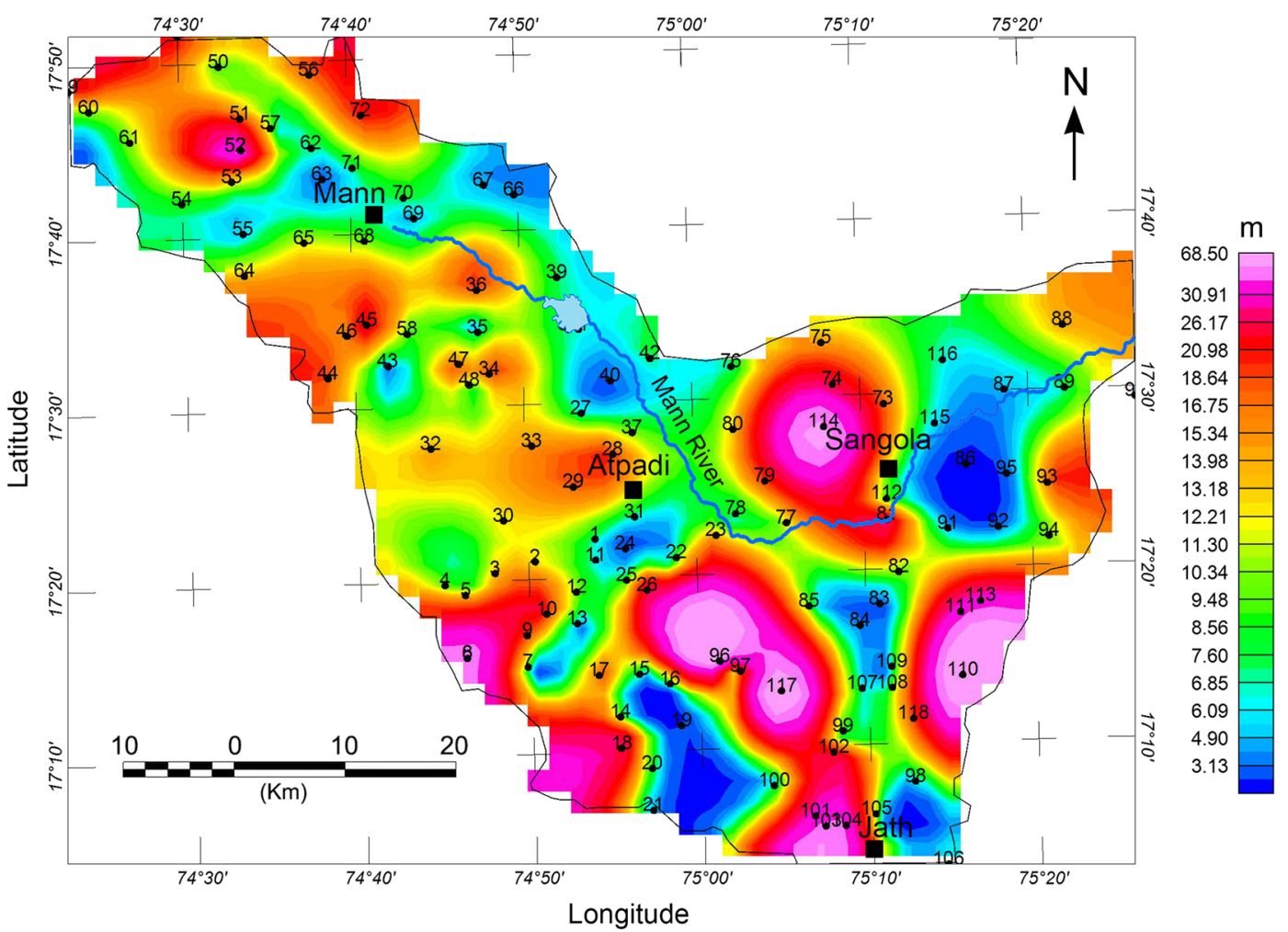

Figure 6. Spatial distribution of aquifer thickness in the study area.

surrounded by the foothills of Western Ghats, is having a thickness ranging from 25 to $70 \mathrm{~m}$. Similarly, stretches of northern and eastern parts reveal aquifer zones with thickness varying from 30 to $60 \mathrm{~m}$. It may be mentioned here that the northeastern part of the study area is underlain by Sangola 


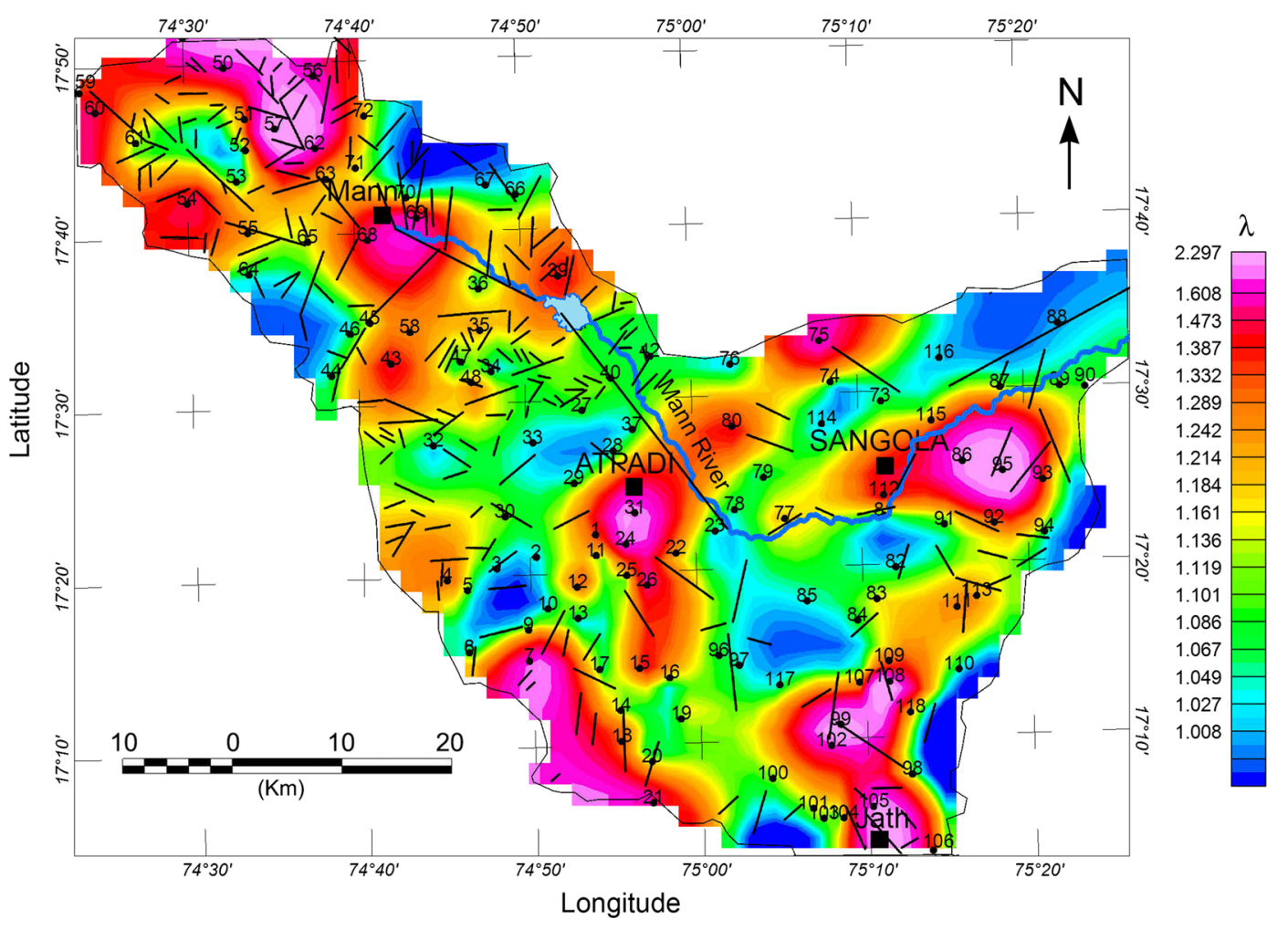

Figure 7. Spatial distribution of electrical anisotropy $(\lambda)$ in the study area.

high as advocated by several researchers (Tiwari et al. 2001; Pandey et al. 2009), to be discussed later.

The average longitudinal resistivity $\rho_{l}$ ranges from 11.5 to $3327 \Omega \mathrm{m}$ in the study area, which helps in calculating the total depth $H$ to the high resistivity bedrock. This wide variation in resistivity values also reveals the degree of subsurface inhomogeneity (Murali and Patangay 2006). Furthermore, the average transverse resistivity $\rho_{t}$ varies from 13.4 to $5045 \Omega \mathrm{m}$, which is more than the average longitudinal resistivity (Salem 1999). This indicates that the current flow and average hydraulic conduction along the lithology boundary are greater than those normal to the boundary plane (Ndatuwong and Yadav 2015).

Based on the estimates of transverse and longitudinal resistivities, the coefficient of electrical anisotropy $\lambda$ is calculated using equation (3). This is a measure of the extent of inhomogeneity in the basement caused due to the near surface effects, extent of weathering and geological features such as fractures, lineaments, faults, etc. (Ayuk et al. 2013). The value of $\lambda$ ranges from 1 to 2.8 with an average of 1.24 in the study area and its distribution is shown in figure 7 .

This dimensionless parameter generally varies between 1 and 2 in most of the geological environments (Zohdy et al. 1974). Keller and Frischknecht (1966) are of the view that $\lambda$ increases with the hardness and compaction of rocks, and therefore, such areas can be related with low porosity and permeability. This parameter is generally used to evaluate the fitness of the underlying geomaterials and identify the locales of potential aquifer zones with high porosity and permeability. Singh and Singh (1970) advocated that an area with $\lambda$ value ranging between 1 and 1.5 is considered to be a potential zone for groundwater.

It can be observed from figure 7 that the coefficient of anisotropy suggests an increasing trend from southwest (SW) to northeast (NE) direction with $\lambda$ values $>1.6$. Similar increasing trend is also observed in the northwest (NW)southeast (SE) direction. This reveals the heterogeneous and anisotropic nature of the subsurface in both NE-SW and NW-SE directions. These stretches are, thus, more fractured in the study area, suggesting reasonably enhanced prospective groundwater zone (Mondal et al. 2013).

For a better understanding of the subsurface features, the lineaments (redrawn after http:// bhuvan.nrsc.gov.in/state/MH) have been superimposed on the electrical anisotropy map (figure 7) that also depicts the course of Mann Ganga River. This river originates near Mann village (VES 68 
and 69) and flows in SE direction until it takes a sharp turn (near VES 78 and 77) and changes its course towards NE direction. It can be seen from the figure 7 that two major lineaments trending NE-SW and NW-SE directions near Sangola is parallel to the course of Mann Ganga River, which is the causative factor for the river to take a sharp turn. Geophysical studies (Krishna Brahmam and Negi 1973; Tiwari et al. 2001; Pandey et al. 2009; Vasanthi and Satish Kumar 2016) have delineated a WNW-ESE trending gravity high around Sangola, which has been attributed to the upliftment of lower crust and uppermost mantle. This suggests that high-density material is underlying beneath this region. Furthermore, Krishna Brahmam and Negi (1973), from residual gravity anomalies, are of the view that the Sangola high is flanked by gravity lows at Karad and Kurduwadi, and the distinct gravity high is due to tectonic activity, indicating displacements in deeper strata. The spatial variation of electrical anisotropy (figure 7 ) reveals high $\lambda$ values near Sangola, marked by lineaments extending in all directions, which might be the surface expression of Sangola high. These have better water-holding capacity from different directions. Furthermore, figure 7 reveals several lineaments criss-crossing the study area, and the intersection points of these lineaments are probably to be the most favourable zone for groundwater recharge.

As mentioned earlier, the electrical anisotropy $\lambda$ ranges from 1 to 2.8 , depicting a broad variation in the study area, suggesting the nature of anisotropy of the geoelectrical parameters. It has been reported by Kumar et al. (2014) that if $\lambda$ exceeds 1 , then the subsurface basaltic formation is more fractured; on the other hand, if the value of $\lambda$ is about 1 , then probably the overburden thickness $H$ is more. In the present study, the maps of electrical anisotropy and aquifer zone thickness suggest that the VES stations with relatively thick overburden are hovering around the $\lambda$ value of 1 . This also reveals that the lineaments are more conspicuous at places with high $\lambda$ values, as can be observed in figure 7 .

Lineaments are the surface expression of the underlying geological structure such as fault. Lineament density map is essentially used to assess the relationship between lineaments and groundwater occurrence. The lineament map was generated from the satellite image, toposheets and field inspection of the study area. The lineament density $\left(L_{d}\right)$ is the fraction of total lineament length divided by the total area of the basin (Edet et al. 1994). The mathematical expression of lineament density is as follows:

$$
\text { Lineament density, } L_{d}=\sum_{i=1}^{n}\left(\frac{L_{i}}{A}\right) \text {, }
$$

where $A$ (in $\mathrm{km}^{2}$ ) is an area of grid and $\sum L_{i}$ is total lineament length (in $\mathrm{km}$ ) in the area under consideration. In the study area, the lineament density ranges from 0 to $2.18 \mathrm{~km} / \mathrm{km}^{2}$ (figure 8 ). High lineament density values generally suggest high-yielding borewells. Therefore, the high lineament density $\left(1.24-2.18 \mathrm{~km} / \mathrm{km}^{2}\right)$ in the central and north western parts of the study area implies high possibilities of groundwater percolation and vice versa.

Rainfall is one of the key parameters which is directly related to the groundwater potential of an area. It determines the amount of water percolated into the subsurface. Rainfall data were obtained from Tropical Rainfall Measuring Mission (TRMM) database and combined with IMD data. The tiled TRMM data were again reclassified to match pixel data size of other layers. Pixel data values were extracted to point layer for preparation of rainfall map of the study area (figure 9). The maximum rainfall (710-1046 mm/yr) is concentrated in the central and eastern parts of the study area.

\subsection{Interrelationship between thematic parameters}

As mentioned earlier, the present study area Mann River basin is underlain by DVP, and groundwater occurs in unconfined and semi-confined conditions. The major rock type in this area is the basaltic rock unit that do not have any primary porosity, and thus, the occurrence and movement of groundwater are possible through the secondary porosity, which is developed due to weathering and fracturing (Deolankar 1980). Groundwater occurrences are mainly concentrated to shallow overburden of weathered materials and fractured bed rocks. In view of this, the main focus of the present study is to locate unconfined aquifers up to depths of $40 \mathrm{~m}$, although deeper confined aquifers at depth of $60 \mathrm{~m}$ and more are also evident at some VES stations.

From the above, it can be inferred that the central and western parts of the study area depict low aquifer resistivity values and moderate aquifer thickness, suggesting that these regions are favourable for groundwater. Moreover, the longitudinal conductance $(S)$ map reveals that these parts of the study area have moderate-to-good 


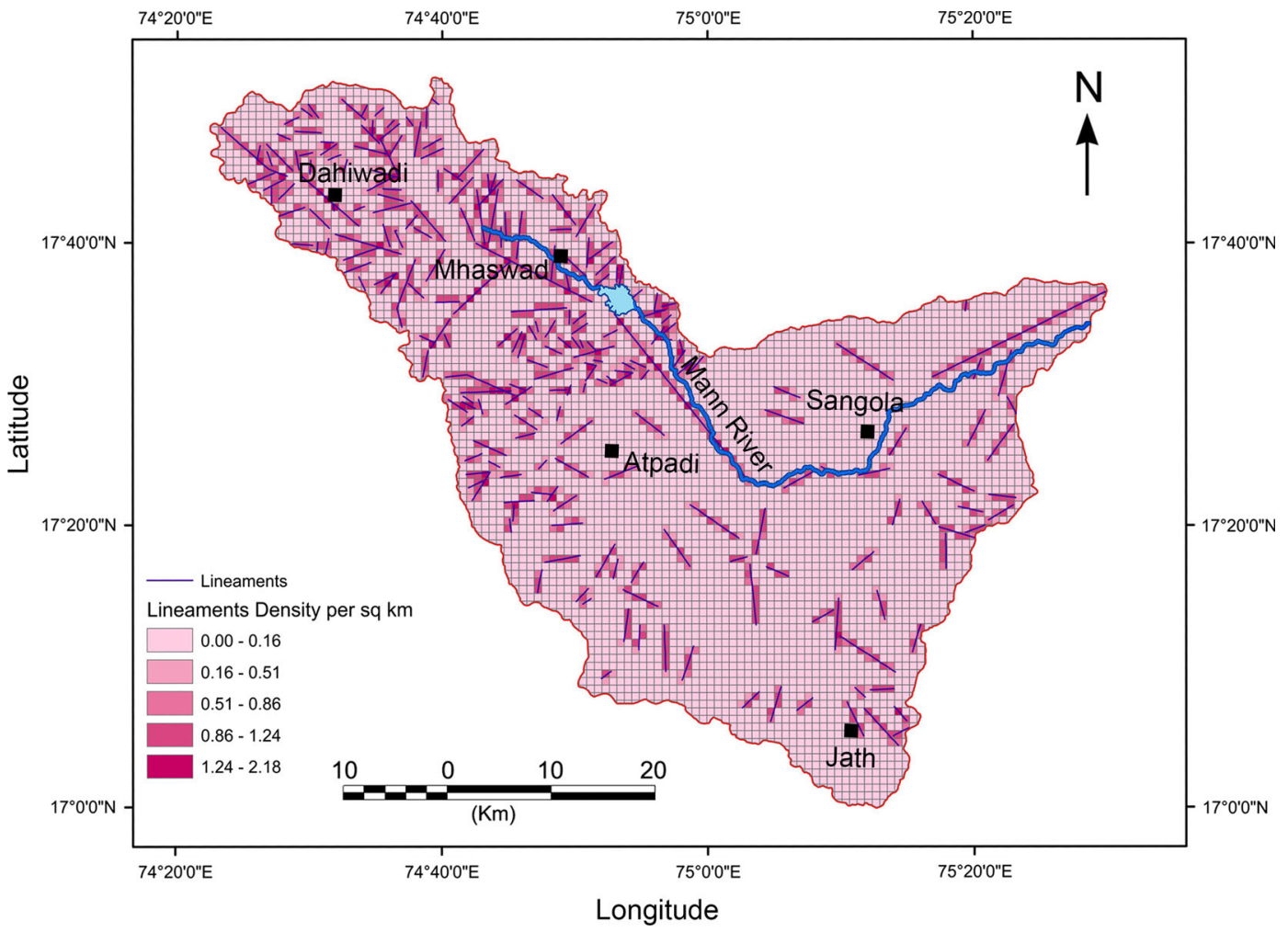

Figure 8. Lineament density $\left(L_{d}\right)$ map of study area.

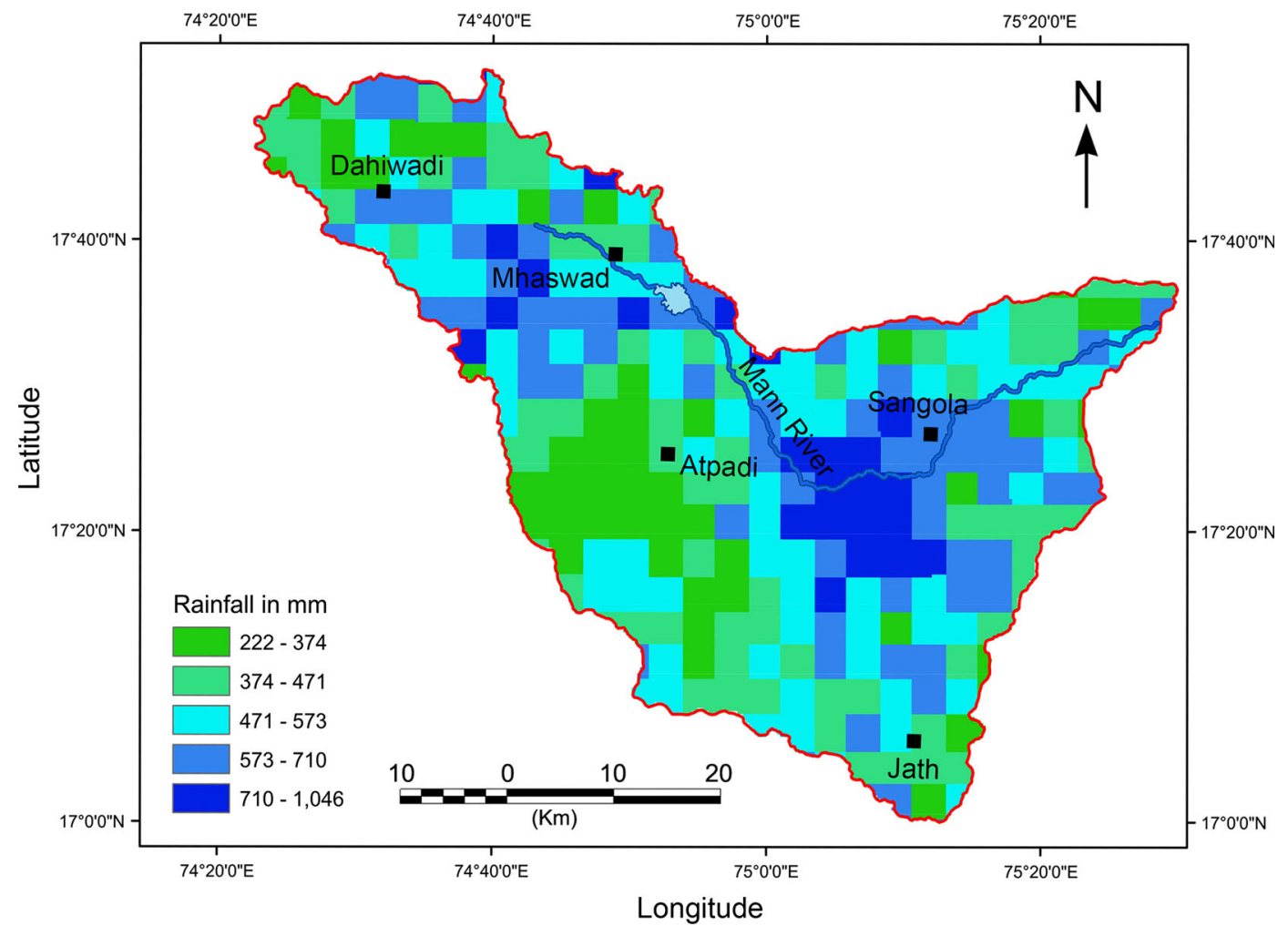

Figure 9. Rainfall distribution map of the study area. 
protective capacity, implying that the overburden clayey layer is considerably thick and offers protection to the underlying aquifers from contaminants. The transverse resistance $(T)$ divulge low values in the central and western parts of the study area, meaning that the transmissivity is low and infiltration of contaminants will be minimum.

It can be deduced from the foregoing that high groundwater potential zones are predominant in the central part of the basin showing low-tomoderate aquifer resistivity and high lineament density. The parallel between electrical anisotropy and lineament density maps (figures 7 and 8) also reveals that regions with high lineament density coincide with the heterogeneity of the subsurface. These stretches, therefore, tend to be more prolific, owing to the openings that exist in the form of joints and fractures that allow groundwater to move easily. Similarly, it is seen from figures 8 and 9 that the regions near Mhaswad and Sangola having highest rainfall are demarcated with high lineament density, which is an indicative of high groundwater recharge zones.

\subsection{Relationship between longitudinal conductance and soil fraction}

The soils of the study area are primarily derived from the Deccan basalt (Deshpande 1998). This region has distinctive landform wherein, the western and northwestern parts are prevalent with structural and denudational hills, whereas the central and eastern portions are characterised by plain area. As this area has a typical climatic condition characterised by meagre rainfall, severe drought is prevalent, distinctive of a semiarid environment. Therefore, the soils will be more fragile and prone to degradation. On the whole, the soil from the study area shows the presence of both nodular as well as powdery calcrete, assortment of clay, sand and silt besides the fragments of weathered basalt (Duraiswami et al. 2012). As mentioned earlier, the study region falls in the rain shadow zone, and thus, there is severe scarcity of water. The problem of water scarcity and contamination is also aggravated due to over irrigation, excessive use of chemical fertilisers and intensive rainless crops cultivation.

The PSA data suggest that silt is dominating the entire basin, followed by sand and finally by clayey type of soil. The clay content varies from a minimum of $5.55 \%$ to a maximum of $32.78 \%$. The silt content varies from 47.47 to $89.55 \%$, whereas the sand content ranges from 0 to $45.42 \%$. As stated earlier, the aquifer protective capacity in the study area is poor $(67 \%)$. This is further established by the fact that the clayey overburden is not thick enough over the entire basin, thereby enhancing the infiltration of contaminants.

As discussed earlier, highly impervious materials such as clay usually have high longitudinal conductance $S$ values, thereby offering good protection to the underlying aquifers, whereas sand have low longitudinal conductance values that are associated with low aquifer protective capacity. The downstream part of the Mann River and its tributaries to the southern side is dominated by silt which is usually more fertile than other types of soils and is useful for agricultural purposes. The spatial distribution of clay in the study area (figure 10) is spread over the entire basin in patches. A look at the spatial distribution of clay and longitudinal conductance map (figure 3) reveals that regions with moderate to high $S$ values are reflected with clayey layer varying from $15 \%$ to $32 \%$. Clay particles are very important in soil fertility as they have high water holding capacity and poor percolation. The sand particles are pervasive in the upstream part of Mann River. In the downstream part, however, it is negligible due to plain topography characterised by alluvial lithology.

It has been reported by Deshmukh and Aher (2014) that particle size distribution influences the moisture retention and transmission properties of soils. This means that coarse textured soils (sand) have low moisture retention and high permeability, whereas fine textured soils (clay) have high moisture retention and low permeability. In the present study area, it can be surmised that regions where soils have high clay content, the contaminated water will have extended travel time to percolate from the surface to the low permeability aquifers, thereby protecting the deep aquifers from pathogen contamination. The clay portion contains larger aluminosilicates and has higher content of humus. Moreover, the electrical resistivity is connected to the particle size by the electrical charge density at the surface. Clay minerals have a high cation exchange capacity, and because of their proportion in weathered crystalline rock terrains, they yield a low electrical resistivity. This is due to the effect of conduction mechanism located in the close vicinity of pore water-mineral interface in the electrical double-layer coating the mineral-water interface (Revil and Leroy 2001). The electrical double-layer contributes to the enhancement of 


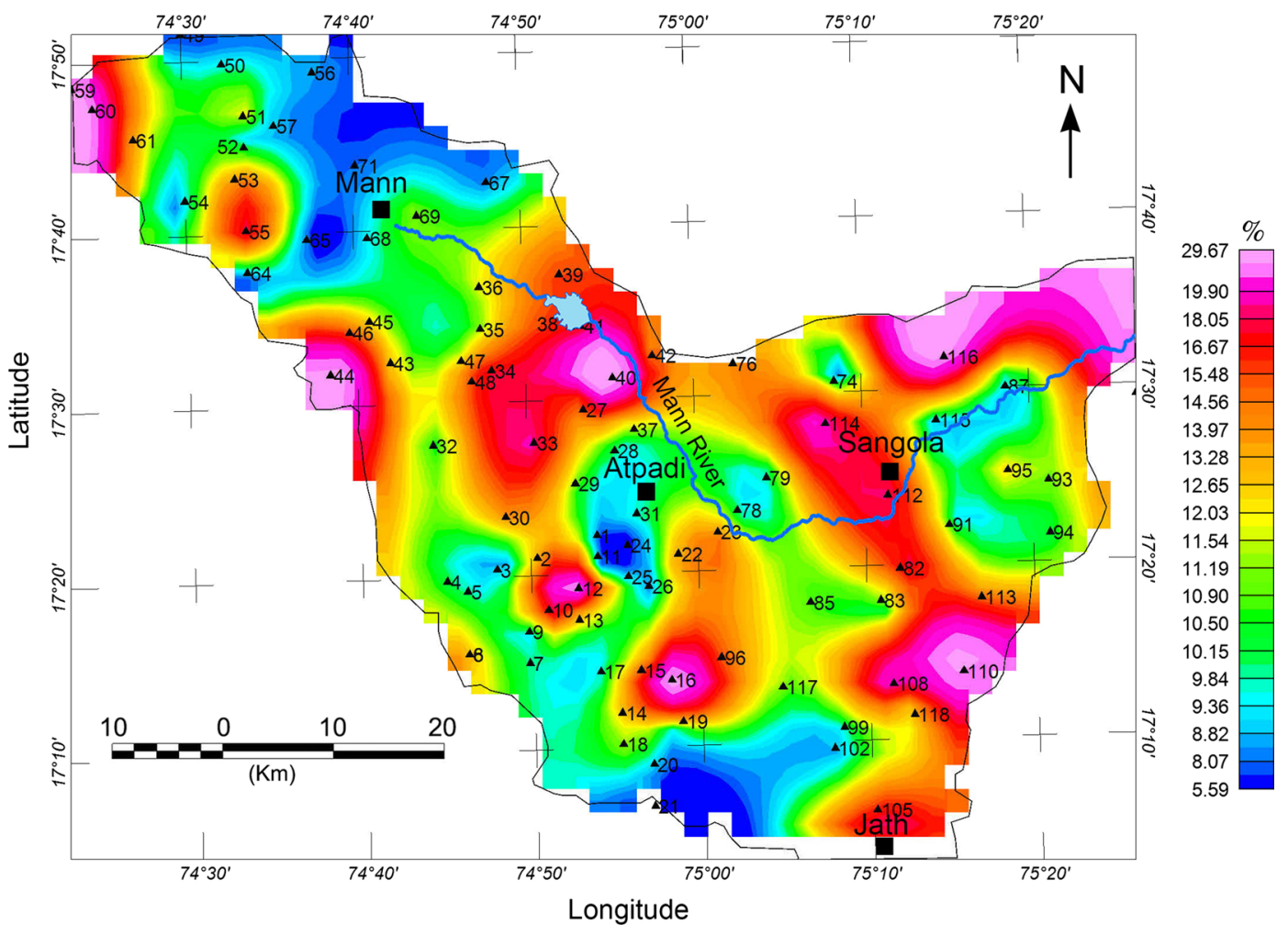

Figure 10. Spatial distribution of clay in the study area.

the electrochemical properties of the clay minerals (Leroy and Revil 2004). In clayey soil, the electrical charges located at the surface of the clay particles lead to lower electrical resistivity than in coarse-textured soils because of the magnitude of the specific surface (Fukue et al. 1999).

\section{Conclusions}

In this study, geoelectrical sounding data have been used to study the aquifer protective capacity and delineating aquiferous zones utilising the secondary geophysical parameters (D-Z parameters) and other thematic parameters in the drought-prone region of southern Maharashtra.

The longitudinal conductance $S$ value varies from a maximum of $1.605 \mathrm{~S}$ to a minimum of 0.0023 $\mathrm{S}$ in the study area. The $S$ map further reveals that about $80 \%$ of the study area is characterised by topsoil with poor-to-weak protective capacity. This implies that alluvium aquifers in the basin are not protected against infiltrating contaminants. This has helped to assess the shallow subsurface materials overlying the aquifers in the study area, thereby enabling the evaluation of the vulnerability of aquifers to surface pollutants such as chemical fertilisers that are commonly used by farmers in the rain-shadow region of the Mann Ganga River basin.

The total transverse resistance $T$ varies from 106 to $1,04,951 \Omega \mathrm{m}^{2}$. High $T$ values in excess of $4000 \Omega \mathrm{m}^{2}$ in central, eastern, southern and northwestern parts of the study area signify fresh water regime. This also reflects high transmissivity and hence highly permeable to fluid movement.

The coefficient of anisotropy divulge an increasing trend from SW-NE and NW-SE directions with $\lambda$ values $>1.6$, revealing the heterogeneous and anisotropic disposition of the subsurface in both these directions. These stretches are, therefore, more fractured suggestive of enhanced potential groundwater zone. Furthermore, several lineaments are traversing throughout the study area, and the intersection points of these lineaments are expected to be the most favourable for groundwater recharge in the area. The lineament density map also corroborate with the heterogeneity of the subsurface. It is also inferred that the central region is characterised by highest rainfall where high lineament density is revealed. These areas are suggestive of high groundwater recharge zones.

The PSA data suggest that silt is dominating the entire basin, followed by sand and clay types of soil. The spatial distribution of clay and longitudinal 
conductance $(S)$ map suggests that regions with moderate to high $S$ values are observed, where the clay overburden is relatively thick.

The estimation of $\mathrm{D}-\mathrm{Z}$ parameters for appraisal of aquifer protection studies is of utmost significance in terms of societal issues such as groundwater exploration and protection from pollution. Furthermore, this result will be useful to achieve a better perceptive of the complex geology of the Mann Ganga River basin and should provide basis for the assessment of large tracts of drought-prone agricultural land using electrical resistivity imaging and VLF-EM to achieve sustainable groundwater management, hydrologic and hydrogeologic evaluations.

\section{Acknowledgements}

The authors are obliged to Dr D S Ramesh, Director, IIG, for providing the necessary facilities required for the survey and for his constant guidance. Financial support as fellowship given to the first author (GS) by IIG is duly acknowledged. The authors appreciate the assistance of Shri B D Kadam and Dr V C Erram during data acquisition. Drafting of figures by Shri B I Panchal is gratefully acknowledged. The authors express their deep sense of gratitude to the anonymous reviewers and Prof M Radhakrishna, Associate Editor, for their critical comments and excellent suggestions for improving this paper.

\section{Appendix}

Table A1. Geoelectrical layers and D-Z parameters in the Mann Ganga River basin, Maharashtra.

\begin{tabular}{|c|c|c|c|c|c|c|c|c|c|c|c|c|c|c|c|c|}
\hline \multirow{2}{*}{$\begin{array}{l}\text { VES } \\
\text { no. }\end{array}$} & \multicolumn{6}{|c|}{ Layer resistivity $(\Omega \mathrm{m})$} & \multicolumn{4}{|c|}{ Layer thickness $(\mathrm{m})$} & \multirow[b]{2}{*}{$H(\mathrm{~m})$} & \multirow[b]{2}{*}{$S$} & \multirow[b]{2}{*}{$T$} & \multirow[b]{2}{*}{$\lambda$} & \multirow[b]{2}{*}{$\rho_{t}$} & \multirow[b]{2}{*}{$\rho_{l}$} \\
\hline & $\rho_{1}$ & $\rho_{2}$ & $\rho_{3}$ & $\rho_{4}$ & $\rho_{5}$ & $\overline{\rho_{6}}$ & $h_{1}$ & $h_{2}$ & $h_{3}$ & $h_{4} \quad h_{5}$ & & & & & & \\
\hline 1 & 61.5 & 191 & 129 & 27.4 & 111 & & 0.5 & 1.93 & 13.5 & 7.1 & 23 & 0.382 & 2335 & 1.29 & 101 & 60 \\
\hline 2 & 30.4 & 97.4 & 80.8 & & & & 0.5 & 11.8 & & & 12.3 & 0.137 & 1164 & 1.02 & 94.6 & 89.7 \\
\hline 3 & 31.5 & 96.4 & 79.3 & & & & 0.5 & 13.8 & & & 14.3 & 0.159 & 1346 & 1.02 & 94.1 & 89.9 \\
\hline 4 & 37.5 & 2024 & 234 & 44 & 35.4 & & 0.5 & 0.187 & 27 & 8.89 & 36.6 & 0.33 & 7106 & 1.32 & 194.1 & 110.9 \\
\hline 5 & 36.5 & 80.2 & 36.2 & 91.3 & & & 0.5 & 2.65 & 8.33 & & 11.5 & 0.27 & 532.3 & 1.04 & 46.2 & 42.5 \\
\hline 6 & 67.3 & 125 & 73.8 & 193 & & & 1.03 & 3.3 & 55.9 & & 60.2 & 0.799 & 4607 & 1 & 76.5 & 75.3 \\
\hline 7 & 263 & 17.5 & 219 & & & & 0.71 & 0.336 & & & 1.05 & 0.021 & 192 & 1.9 & 183 & 50 \\
\hline 8 & 48.5 & 136 & 62.7 & 163 & & & 1 & 9.23 & 34.5 & & 44.8 & 0.638 & 3466.9 & 1.04 & 77.3 & 70.2 \\
\hline 9 & 16.1 & 134 & 55.9 & 105 & & & 1.32 & 3.19 & 18.8 & & 23.3 & 0.43 & 1499 & 1.09 & 64.3 & 54.1 \\
\hline 10 & 41 & 106 & 98 & & & & 0.5 & 25 & & & 25.5 & 0.248 & 2670 & 1.01 & 104.7 & 102 \\
\hline 11 & 59.9 & 198 & 135 & 89.5 & & & 0.557 & 2.96 & 21.9 & & 25.4 & 0.186 & 3575 & 1.01 & 140.7 & 136 \\
\hline 12 & 20.8 & 189 & 82.8 & & & & 2.22 & 10.6 & & & 12.8 & 0.162 & 2049 & 1.42 & 160 & 79 \\
\hline 13 & 120 & 90.3 & 116 & & & & 0.613 & 2.17 & & & 2.78 & 0.029 & 269.5 & 1 & 96.9 & 95 \\
\hline 14 & 35.3 & 226 & 61.3 & & & & 0.565 & 8.14 & & & 8.71 & 0.05 & 1859 & 1.1 & 213.4 & 174.2 \\
\hline 15 & 47.6 & 101 & 668 & 103 & & & 0.738 & 6.75 & 3.03 & & 10.5 & 0.086 & 2740 & 1.46 & 261 & 122 \\
\hline 16 & 55.8 & 107 & 75.7 & & & & 0.5 & 3.2 & & & 3.7 & 0.038 & 370.3 & 1.01 & 100 & 97.3 \\
\hline 17 & 107 & 282 & 70.3 & & & & 2.94 & 19.8 & & & 22.8 & 0.097 & 5898 & 1.04 & 258.6 & 235 \\
\hline 18 & 119 & 32.6 & 410 & 26.9 & 4430 & & 2.13 & 1.046 & 3.37 & 35.3 & 42.2 & 1.38 & 2632 & 1.42 & 62.3 & 30.5 \\
\hline 19 & 49 & 206 & 106 & & & & 0.5 & 0.934 & & & 1.43 & 0.014 & 216.9 & 1.21 & 151 & 102 \\
\hline 20 & 24.7 & 37.3 & 125 & & & & 0.5 & 6.21 & & & 6.71 & 0.186 & 243.9 & 1 & 363 & 36 \\
\hline 21 & 34.3 & 155 & 897 & 42.5 & & & 0.587 & 3.86 & 2.94 & & 7.38 & 0.045 & 3255 & 1.63 & 441 & 164 \\
\hline 22 & 189 & 415 & 95.8 & & & & 0.556 & 0.628 & & & 1.18 & 0.0044 & 365 & 1.07 & 309.9 & 268 \\
\hline 23 & 108 & 203 & 46.7 & & & & 1.8 & 16.9 & & & 18.7 & 0.099 & 3625 & 1.01 & 193.8 & 188 \\
\hline 24 & 43.5 & 503 & 105 & & & & 0.5 & 0.329 & & & 0.829 & 0.012 & 187 & 1.8 & 225 & 69 \\
\hline 25 & 60.6 & 680 & 162 & 90.9 & & & 0.5 & 0.274 & 8.2 & & 8.97 & 0.059 & 1545 & 1.06 & 172 & 152 \\
\hline 26 & 104 & 225 & 17.7 & 1487 & & & 0.659 & 6.39 & 27.8 & & 34.8 & 1.605 & 1998 & 1.6 & 57.4 & 21.6 \\
\hline 27 & 89.5 & 132 & 108 & 278 & 64.2 & & 0.5 & 2.14 & 12 & 6.49 & 21.2 & 0.156 & 3427 & 1.09 & 161 & 135 \\
\hline 28 & 58.1 & 149 & 72.4 & & & & 0.669 & 21.3 & & & 22 & 0.154 & 3212 & 1.01 & 146 & 142 \\
\hline 29 & 46 & 123 & 50 & 113 & & & 0.5 & 2.88 & 17.6 & & 21 & 0.386 & 1257.2 & 1.04 & 59.8 & 54.4 \\
\hline 30 & 61.4 & 84.4 & 235 & 107 & & & 0.5 & 5.54 & 12.2 & & 18.2 & 0.125 & 3365 & 1.12 & 184 & 145 \\
\hline 31 & 50.1 & 166 & 10.2 & 19190 & & & 1.38 & 3.14 & 7.37 & & 11.9 & 0.769 & 665 & 1.9 & 55.9 & 15.4 \\
\hline 32 & 33.7 & 176 & 84.1 & & & & 0.515 & 14.6 & & & 15.1 & 0.098 & 2586 & 1.01 & 171 & 167.7 \\
\hline
\end{tabular}


Table A1. (Continued.)

\begin{tabular}{|c|c|c|c|c|c|c|c|c|c|c|c|c|c|c|c|c|c|}
\hline \multirow{2}{*}{$\begin{array}{l}\text { VES } \\
\text { no. }\end{array}$} & \multicolumn{6}{|c|}{ Layer resistivity $(\Omega \mathrm{m})$} & \multicolumn{5}{|c|}{ Layer thickness (m) } & \multirow[b]{2}{*}{$H(\mathrm{~m})$} & \multirow[b]{2}{*}{$S$} & \multirow[b]{2}{*}{$T$} & \multirow[b]{2}{*}{$\lambda$} & \multirow[b]{2}{*}{$\rho_{t}$} & \multirow[b]{2}{*}{$\rho_{l}$} \\
\hline & $\rho_{1}$ & $\rho_{2}$ & $\rho_{3}$ & $\rho_{4}$ & $\rho_{5}$ & $\rho_{6}$ & $h_{1}$ & $h_{2}$ & $h_{3}$ & $h_{4}$ & $h_{5}$ & & & & & & \\
\hline 33 & 59.8 & 208 & 146 & 75.2 & & & 0.5 & 2.26 & 15.6 & & & 18.3 & 0.126 & 2777 & 1.02 & 151.7 & 145 \\
\hline 34 & 34.7 & 94.3 & 70.7 & & & & 0.506 & 20.4 & & & & 20.9 & 0.23 & 1941 & 1.01 & 92.8 & 90 \\
\hline 35 & 45.3 & 208 & 75.8 & & & & 1.22 & 2.79 & & & & 4.01 & 0.04 & 635.5 & 1.25 & 158 & 100 \\
\hline 36 & 58.5 & 83.7 & 169 & 62.8 & & & 0.5 & 5.81 & 20.7 & & & 27 & 0.2 & 4013.8 & 1.04 & 148 & 135 \\
\hline 37 & 53.9 & 157 & 79.9 & & & & 0.596 & 9.81 & & & & 10.4 & 0.073 & 1572.2 & 1.03 & 151.1 & 142 \\
\hline 38 & 43.4 & 155 & 33.5 & 67.6 & & & 0.609 & 2.74 & 6.57 & & & 9.92 & 0.227 & 671.2 & 1.24 & 67.6 & 43.7 \\
\hline 39 & 42.2 & 903 & 0.861 & & & & 0.5 & 7.28 & & & & 7.78 & 0.019 & 6594 & 1.43 & 847 & 409 \\
\hline 40 & 18.5 & 84.8 & 47 & & & & 6.02 & 0.553 & & & & 6.58 & 0.331 & 158.2 & 1.12 & 24 & 19 \\
\hline 41 & 5.16 & 15.1 & 64.7 & & & & 1.25 & 6.64 & & & & 7.88 & 0.68 & 106 & 1.08 & 13.4 & 11.5 \\
\hline 42 & 37.5 & 117 & 198 & 59.2 & & & 0.5 & 3.54 & 8.21 & & & 12.3 & 0.085 & 2058 & 1.07 & 167 & 144 \\
\hline 43 & 90.3 & 365 & 86.0 & 597 & 54.6 & & 0.644 & 0.628 & 3.72 & 3.33 & & 8.32 & 0.057 & 2595 & 1.46 & 311.9 & 145 \\
\hline 44 & 23.6 & 121 & 77.8 & & & & 0.911 & 19.2 & & & & 20.1 & 0.197 & 2344 & 1.06 & 116 & 102 \\
\hline 45 & 103 & 164 & 43.7 & 114 & & & 0.677 & 5.18 & 25 & & & 30.8 & 0.61 & 2011 & 1.14 & 65 & 50 \\
\hline 46 & 59.9 & 196 & 54 & & & & 0.573 & 13.1 & & & & 13.7 & 0.076 & 2601 & 1.02 & 189.9 & 180 \\
\hline 47 & 80.9 & 107 & 74.6 & 52.9 & & & 0.73 & 2.45 & 20.5 & & & 23.7 & 0.306 & 1850 & 1 & 78 & 77 \\
\hline 48 & 52 & 96.7 & 18.1 & 107 & & & 1.14 & 14.9 & 6.62 & & & 22.7 & 0.54 & 1619 & 1.3 & 71.3 & 42 \\
\hline 49 & 230 & 1401 & 275 & 2277 & 503 & & 0.5 & 0.836 & 2.23 & 22.4 & & 26 & 0.99 & 2409 & 1.8 & 92.6 & 26 \\
\hline 50 & 4270 & 656 & 139 & 126582 & & & 0.774 & 4.27 & 9.28 & & & 14.3 & 0.073 & 7396 & 1.62 & 517 & 195 \\
\hline 51 & 966 & 9379 & 1797 & 404 & & & 1.38 & 2.95 & 15.5 & & & 19.8 & 0.01 & 56854 & 1.2 & 2871 & 1980 \\
\hline 52 & 309 & 2067 & 21.9 & & & & 1.84 & 43.2 & & & & 45 & 0.026 & 89862 & 1.07 & 1996 & 1730 \\
\hline 53 & 418 & 1142 & 560 & & & & 0.581 & 6.55 & & & & 7.13 & 0.0071 & 7722 & 1.03 & 1083 & 1004 \\
\hline 54 & 1320 & 433 & 6768 & 721 & & & 3.92 & 2.94 & 7.68 & & & 14.5 & 0.01 & 58425 & 1.6 & 4029 & 1450 \\
\hline 55 & 1901 & 1201 & 5206 & 678 & & & 2.3 & 5.35 & 4.48 & & & 12.1 & 0.0065 & 34120 & 1.24 & 2879 & 1861 \\
\hline 56 & 412 & 5475 & 325 & 5598 & 25.3 & & 0.5 & 0.524 & 1.7 & 18.1 & & 20.8 & 0.0097 & 104951 & 1.53 & 5045 & 2144 \\
\hline 57 & 532 & 2157 & 78.7 & 789 & & & 0.923 & 2.87 & 5.89 & & & 9.68 & 0.077 & 7145 & 2.42 & 738 & 125 \\
\hline 58 & 109 & 1569 & 427 & & & & 0.529 & 8.85 & & & & 9.38 & 0.01 & 13943 & 1.25 & 1486 & 938 \\
\hline 59 & 190 & 1333 & 12.7 & & & & 4.1 & 30.2 & & & & 34.3 & 0.044 & 41035 & 1.23 & 1196 & 779 \\
\hline 60 & 149 & 1140 & 6030 & 141 & & & 0.513 & 9.79 & 11.1 & & & 21.4 & 0.013 & 78170 & 1.48 & 3652 & 1646 \\
\hline 61 & 1673 & 376 & 1900 & 666 & & & 0.944 & 0.583 & 10.9 & & & 12.5 & 0.0078 & 22508 & 1.05 & 1800 & 1602 \\
\hline 62 & 1077 & 2617 & 253 & 549 & & & 0.876 & 2.95 & 8.53 & & & 12.4 & 0.035 & 10821 & 1.56 & 872.6 & 354 \\
\hline 63 & 369 & 1450 & 1017 & & & & 0.649 & 2.28 & & & & 2.93 & 0.0033 & 3545 & 1.16 & 1210 & 887 \\
\hline 64 & 2230 & 653 & 2418 & 463 & & & 0.522 & 0.393 & 14.7 & & & 15.6 & 0.0069 & 36965 & 1.02 & 2369 & 2260 \\
\hline 65 & 886 & 3249 & 346 & 835 & & & 1.86 & 2.9 & 12.1 & & & 16.9 & 0.037 & 15256 & 1.14 & 902 & 456 \\
\hline 66 & 2600 & 965 & 653 & & & & 0.746 & 4.07 & & & & 4.82 & 0.0045 & 5867 & 1.06 & 1217 & 1071 \\
\hline 67 & 975 & 1489 & 1008 & & & & 0.5 & 3.07 & & & & 3.57 & 0.00257 & 5058.7 & 1.01 & 1417 & 1389 \\
\hline 68 & 3391 & 650 & 1675 & 221 & 1584 & & 0.5 & 2.29 & 10.6 & 10.2 & & 23.6 & 0.056 & 23193 & 1.52 & 982 & 421 \\
\hline 69 & 3699 & 1683 & 203 & 833 & & & 0.5 & 3.1 & 3.64 & & & 7.24 & 0.019 & 7805 & 1.68 & 1078 & 381 \\
\hline 70 & 1205 & 344 & 447 & 1185 & & & 0.5 & 0.836 & 8.2 & & & 9.53 & 0.021 & 4555 & 1.02 & 478 & 453 \\
\hline 71 & 524 & 4544 & 669 & 2197 & 832 & & 0.5 & 0.129 & 6.04 & 7.2 & & 13.9 & 0.013 & 20707 & 1.18 & 1489 & 1069 \\
\hline 72 & 713 & 7768 & 147 & 2531 & 418 & 1062 & 0.5 & 0.233 & 0.644 & 1.97 & 21.8 & 25.1 & 0.052 & 6359 & 1.16 & 651.7 & 482 \\
\hline 73 & 1124 & 4205 & 455 & & & & 1.89 & 17.4 & & & & 19.3 & 0.0058 & 75291 & 1.08 & 3901 & 3327 \\
\hline 74 & 478 & 1079 & 455 & & & & 0.5 & 24.1 & & & & 24.6 & 0.0233 & 26242 & 1 & 1066 & 1055 \\
\hline 75 & 392 & 130 & 1589 & 650 & & & 0.714 & 4.56 & 14.6 & & & 19.9 & 0.046 & 24072 & 1.67 & 1209 & 432 \\
\hline 76 & 1230 & 912 & 564 & & & & 0.5 & 6.86 & & & & 7.36 & 0.0079 & 6871 & 1 & 933 & 931 \\
\hline 77 & 608 & 1082 & 4248 & 164 & & & 0.906 & 18.6 & 10 & & & 29.6 & 0.021 & 63156 & 1.23 & 2133 & 1409 \\
\hline 78 & 90.9 & 38.6 & 893 & & & & 0.5 & 5 & & & & 5.5 & 0.135 & 238.4 & 1.04 & 43.3 & 40 \\
\hline 79 & 1443 & 973 & 500 & & & & 0.5 & 19.7 & & & & 20.2 & 0.0205 & 19889 & 1 & 984.6 & 981 \\
\hline 80 & 866 & 3100 & 381 & 929 & & & 3.11 & 5.63 & 12.9 & & & 21.6 & 0.039 & 25061 & 1.44 & 1160 & 553.8 \\
\hline 81 & 1213 & 2666 & 869 & 168 & & & 3.91 & 1.51 & 28.5 & & & 33.9 & 0.036 & 33534 & 1.02 & 989 & 941 \\
\hline 82 & 46.6 & 20.3 & 39.8 & 2774 & & & 0.5 & 0.928 & 8.11 & & & 9.54 & 0.26 & 364 & 1.03 & 38.2 & 36 \\
\hline 83 & 193 & 51.5 & 163 & & & & 0.636 & 1.52 & & & & 2.16 & 0.032 & 201 & 1.17 & 93 & 67.5 \\
\hline 84 & 790 & 309 & 1179 & & & & 2.21 & 3.86 & & & & 6.07 & 0.015 & 2938 & 1.09 & 484 & 404 \\
\hline 85 & 216 & 443 & 204 & 1301 & & & 0.68 & 2.83 & 6.69 & & & 10.2 & 0.042 & 2765 & 1.05 & 271 & 242 \\
\hline
\end{tabular}


Table A1. (Continued.)

\begin{tabular}{|c|c|c|c|c|c|c|c|c|c|c|c|c|c|c|c|c|c|}
\hline \multirow{2}{*}{$\begin{array}{l}\text { VES } \\
\text { no. }\end{array}$} & \multicolumn{6}{|c|}{ Layer resistivity $(\Omega \mathrm{m})$} & \multicolumn{5}{|c|}{ Layer thickness (m) } & \multirow[b]{2}{*}{$H(\mathrm{~m})$} & \multirow[b]{2}{*}{$S$} & \multirow[b]{2}{*}{$T$} & \multirow[b]{2}{*}{$\lambda$} & \multirow[b]{2}{*}{$\rho_{t}$} & \multirow[b]{2}{*}{$\rho_{l}$} \\
\hline & $\rho_{1}$ & $\rho_{2}$ & $\rho_{3}$ & $\rho_{4}$ & $\rho_{5}$ & $\rho_{6}$ & $h_{1}$ & $h_{2}$ & $h_{3}$ & $h_{4}$ & $\overline{h_{5}}$ & & & & & & \\
\hline 86 & 237 & 2896 & 1185 & & & & 0.524 & 0.507 & & & & 1.03 & 0.0023 & 1592 & 1.88 & 1546 & 434 \\
\hline 87 & 1242 & 774 & 1913 & 582 & & & 0.5 & 3.26 & 4.7 & & & 8.46 & 0.007 & 12135 & 1.08 & 1434 & 1208 \\
\hline 88 & 395 & 619 & 693 & & & & 0.5 & 14.4 & & & & 14.9 & 0.0245 & 9111 & 1 & 611.4 & 608 \\
\hline 89 & 180 & 71.3 & 394 & & & & 3.46 & 6.26 & & & & 9.72 & 0.107 & 1069 & 1.1 & 109.9 & 908 \\
\hline 90 & 765 & 1082 & 344 & 870 & & & 0.5 & 8.81 & 14.5 & & & 23.8 & 0.05 & 14902 & 1.14 & 626 & 476 \\
\hline 91 & 116 & 185 & 31.7 & 318 & & & 0.883 & 3.46 & 4.69 & & & 9.03 & 0.041 & 2229 & 1.05 & 246 & 220 \\
\hline 92 & 133 & 23.6 & 32816 & & & & 0.635 & 2.38 & & & & 3.02 & 0.1 & 140.6 & 1.24 & 46.5 & 30.2 \\
\hline 93 & 101 & 400 & 1398 & 335 & & & 0.731 & 13.3 & 19.8 & & & 33.9 & 0.054 & 33074 & 1.24 & 975 & 627 \\
\hline 94 & 648 & 287 & 980 & & & & 1.4 & 8.02 & & & & 9.42 & 0.03 & 3208 & 1.04 & 340 & 314 \\
\hline 95 & 219 & 438 & 7483 & 585 & & & 0.554 & 2.31 & 2.02 & & & 4.88 & 0.008 & 16248 & 2.3 & 3329 & 610 \\
\hline 96 & 572 & 802 & 1338 & 84.6 & & & 0.5 & 3.47 & 75.7 & & & 79.7 & 0.061 & 104355 & 1.04 & 1309 & 1207 \\
\hline 97 & 98.2 & 1808 & 269 & 2032 & & & 0.5 & 3.08 & 596 & & & 9.54 & 0.028 & 7220 & 1.049 & 756 & 340 \\
\hline 98 & 86.2 & 33.1 & 716 & & & & 0.787 & 4.75 & & & & 5.54 & 0.152 & 225 & 1.06 & 40.6 & 36 \\
\hline 99 & 843 & 14028 & 1285 & 3768 & 147 & 1087 & 0.5 & 0.125 & 2.8 & 4.71 & 2.9 & 11 & 0.023 & 23946 & 2.19 & 2176 & 478 \\
\hline 100 & 2406 & 814 & 1373 & & & & 0.511 & 4.44 & & & & 4.95 & 0.0056 & 4843 & 1.1 & 978 & 883 \\
\hline 101 & 1566 & 362 & 876 & & & & 0.583 & 14.2 & & & & 14.8 & 0.039 & 6053 & 1.03 & 409 & 379 \\
\hline 102 & 1224 & 33.6 & 260 & 2271 & 11.5 & & 0.5 & 0.156 & 7.59 & 29.8 & & 38 & 0.047 & 70266 & 1.5 & 1849 & 808 \\
\hline 103 & 1159 & 2033 & 225 & 4032 & & & 3.57 & 5.96 & 59.5 & & & 69 & 0.27 & 29641 & 1.29 & 429 & 255 \\
\hline 104 & 821 & 5612 & 1356 & 836 & & & 2.58 & 1.44 & 38.9 & & & 43 & 0.032 & 62947 & 1.09 & 1618 & 1343 \\
\hline 105 & 975 & 258 & 9385 & 1152 & & & 2.53 & 1.54 & 1.85 & & & 5.91 & 0.008 & 20226 & 2.15 & 3422 & 738 \\
\hline 106 & 40 & 22.5 & 526 & & & & 1.32 & 10.8 & & & & 12.1 & 0.513 & 295 & 1.02 & 24.4 & 23 \\
\hline 107 & 807 & 1526 & 3301 & 862 & & & 0.5 & 3.38 & 6.25 & & & 10.1 & 0.004 & 26192 & 1.01 & 2593 & 2525 \\
\hline 108 & 257 & 177 & 6287 & 237 & & & 1.17 & 524 & 10.4 & & & 16.8 & 0.035 & 66612 & 2.8 & 3965 & 480 \\
\hline 109 & 137 & 80.6 & 652 & & & & 0.5 & 2.05 & & & & 2.55 & 0.029 & 233 & 1.02 & 91.6 & 87 \\
\hline 110 & 220 & 1320 & 62.5 & & & & 1.38 & 62.6 & & & & 64 & 0.053 & 82935 & 1.03 & 1295 & 1207 \\
\hline 111 & 557 & 124 & 1036 & 41.5 & & & 0.551 & 0.741 & 64.7 & & & 66 & 0.069 & 67427 & 1.03 & 1021 & 956 \\
\hline 112 & 68.1 & 373 & 939 & & & & 0.5 & 7 & & & & 7.5 & 0.046 & 2645 & 1.46 & 325.6 & 163 \\
\hline 113 & 327 & 981 & 6050 & 608 & & & 1.33 & 9.48 & 6.03 & & & 16.8 & 0.014 & 46216 & 1.51 & 2750 & 1200 \\
\hline 114 & 936 & 431 & 372 & 551 & & & 0.5 & 3.25 & 51.1 & & & 54.9 & 0.14 & 20877 & 1 & 380 & 378 \\
\hline 115 & 109 & 16.5 & 113 & 670 & & & 0.626 & 0.571 & 5.65 & & & 6.85 & 0.09 & 716 & 1.16 & 104 & 76 \\
\hline 116 & 24.7 & 37.3 & 125 & & & & 0.5 & 6.21 & & & & 6.71 & 0.186 & 243 & 1 & 36.3 & 36 \\
\hline 117 & 704 & 3291 & 796 & 5682 & & & 0.541 & 0.236 & 63.7 & & & 64.5 & 0.087 & 51093 & 1.03 & 792 & 741 \\
\hline 118 & 436 & 2043 & 641 & & & & 1.07 & 19 & & & & 20.1 & 0.011 & 39283 & 1.03 & 1954 & 1827 \\
\hline
\end{tabular}

\section{References}

Adejumo S A, Oyerinde A O and Aleem M O 2015 Integrated geophysical and geotechnical subsoil evaluation for pre-foundation study of proposed site of Vocational Skill and Entrepreneurship Center at The Polytechnic, Ibadan, SW, Nigeria; Int. J. Sci. Eng. Res. 6(6) 910917.

Ali Kaya M, Özürlan G and Balkaya Ç 2015 Geoelectrical investigation of seawater intrusion in the coastal urban area of Çanakkale, NW Turkey; Environ. Earth Sci. 73(3) 1151-1160.

Ayuk M A, Adelusi A O and Adiat K A N 2013 Evaluation of groundwater potential and aquifer protective capacity assessment at Tutugbua-Olugboyega area, off Ondo road, Akure Southwestern Nigeria; Int. J. Phys. Sci. 8(1) 3750.
Batayneh A T and Al-Taani A A 2016 Integrated resistivity and water chemistry for evaluation of groundwater quality of the Gulf of Aqaba coastal area in Saudi Arabia; Geosci. J. 20(3) 403-413.

Bhattacharya B B and Shalivahan 2016 Geoelectric methods: Theory and application; McGraw Hill Education (India) Pvt. Ltd, India.

Bobachev A 2003 Resistivity sounding interpretation; IPI2WIN: Version 3.0.1, a 7.01.03, Moscow State University.

CGWB 2013 Groundwater information: Satara district, Maharashtra; Tech. Rep. No. 1798/DBR/2013, Govt. of India Ministry of Water Resources Central Ground Water Board.

Dahlin T 2000 Electrode charge-up effects in DC resistivity data acquisition using multi electrode arrays; Geophys. Prospect. 48(1) 181-187. 
Davis S N and DeWiest R J M 1966 Hydrogeology; John Wiley \& Sons, New York, 463p.

Delgado-Rodríguez O, Peinado-Guevara H J, Green-Ruíz C R, Herrera-Barrientos J and Shevnin V 2011 Determination of hydraulic conductivity and fines content in soils near an unlined irrigation canal in Guasave, Sinaloa, Mexico; J. Soil Sci. Plant Nutr. 11(3) 1331.

Deolankar S B 1980 The Deccan Basalt of Maharashtra, India - Their potential as aquifers; Groundwater 18(5) 434-437.

Deshmukh K and Aher S 2014 Particle size analysis of soils and its interpolation using GIS technique from Sangamner area, MS, India; Int. Res. J. Env. Sci. 3(10) 32 37.

Deshpande G G 1998 Geology of Maharashtra; Geological Society of India, Bangalore.

Dolui G, Chatterjee S and Das Chatterjee N 2016 Geophysical and geochemical alteration of rocks in granitic profiles during intense weathering in southern Purulia district, West Bengal, India; Model Earth Syst. Environ. 2 132, https://doi.org/10.1007/s40808-016-0188-5.

Duraiswami R A, Maskare B and Patankar U 2012 Geochemistry of groundwater in the arid regions of Deccan trap country, Maharashtra, India; Mem. Ind. Soc. Appl. Geochem. 1 60-86.

Edet A E, Teme S C, Okereke C S and Esu E O 1994 Lineament analysis for groundwater exploration in Precambrian Oban massif and Obudu plateau, SE Nigeria; J. Mining Geol. 30 87-95.

Engelman R and Leroy P 1993 Sustaining water: Population and the future of renewable water supplies; Population Action International, Washington, DC, 56p.

Fukue M, Minatoa T, Horibe H and Taya N 1999 The microstructure of clay given by resistivity measurements; Eng. Geol. 54 43-53.

Gómez-Puentes F J, Pérez-Flores M A, Reyes-López J A, Lopez D L, Herrera-Barrientos F, García-Cueto R O, Romero-Hernández S, Solís-Domínguez F A and MartínLoeches Garrido M 2016 Geochemical modeling and lowfrequency geoelectrical methods to evaluate the impact of an open dump in arid and deltaic environments; Environ. Earth Sci. 75 1062, https://doi.org/10.1007/ s12665-016-5860-6.

Henriet J P 1976 Direct application of Dar-Zarrouk parameters in ground water surveys; Geophys. Prospect. 24344 353.

Inakwu O A O, Alison J T and John T 2003 Spatial prediction of soil particle-size fractions as compositional data; J. Soil Sci. 168(7) 501-515.

Islami N, Taib S H, Yusoff I and Ghani A A 2012 Integrated geoelectrical resistivity, hydrochemical and soil property analysis methods to study shallow groundwater in the agriculture area, Machang, Malaysia; Environ. Earth Sci. 65 699-712, https://doi.org/10.1007/s12665-011-1117-6.

Keller G V and Frischknecht F C 1966 Electrical methods in geophysical prospecting; Pergamon, Oxford.

Kotra K K, Yedluri I, Prasad S and Pasupureddi S 2016 Integrated geophysical and geochemical assessment for the comprehensive study of the groundwater; Water Air Soil Pollut. 227 211, https://doi.org/10.1007/ s11270-016-2902-3.
Krishna Brahmam N and Negi J G 1973 Rift valleys beneath Deccan trap, India; Geophys. Res. Bull. 11 207-237.

Kumar D, Thiagarajan S and Rai S N 2011 Deciphering geothermal resources in Deccan Trap Region using electrical resistivity tomography technique; J. Geol. Soc. India 78 541-548.

Kumar D, Rai S N, Thiagarajan S and Ratnakumari Y 2014 Evaluation of heterogeneous aquifers in hardrocks from resistivity sounding data in parts of Kalmeshwar taluk of Nagpur district, India; Curr. Sci. 107(7) 11371145 .

Lal R and Stewart B A 1994 Soil processes and water quality. Advances in Soil Science; Lewis Publishers, Boca Raton, FL, 398p.

Leroy P and Revil A 2004 A triple-layer model of the surface electrochemical properties of clay minerals; J. Colloid. Interface Sci. 270 371-380.

Machender G, Dhakate R, Mallikharjuna Rao S T, Mangaraja Rao M and Prasanna L 2014 Heavy metal contamination in sediments of Balanagar Industrial area, Hyderabad, Andhra Pradesh, India; Arab J. Geosci. 7(2) 513-525.

Maillet R 1947 The fundamental equation of electrical prospecting; Geophysics 12 529-556.

Maiti S, Erram V C, Gupta G, Tiwari R K, Kulkarni U D and Sangpal R R 2013 Assessment of groundwater quality: A fusion of geochemical and geophysical information via Bayesian Neural Networks; Environ. Monit. Assess. 185 3445-3465 https://doi.org/10.1007/ s10661-012-2802-y.

Mondal N C, Singh V P and Ahmed S 2013 Delineating shallow saline groundwater zones from Southern India using geophysical indicators; Environ. Monit. Assess. 1854869 4886.

Mondal N C, Tiwari K K, Sharma K C and Ahmed S 2016 A diagnosis of groundwater quality from a semiarid region in Rajasthan, India; Arab. J. Geosci. 9 602, https://doi. org/10.1007/s12517-016-2619-z.

Murali S and Patangay N S 2006 Principles of application of groundwater geophysics; 3rd edn, Association of Geophysicists, Hyderabad, India, 371p.

Ndatuwong L G and Yadav G S 2015 Application of geo-electrical data to evaluate groundwater potential zone and assessment of overburden protective capacity in part of Sonebhadra district, Uttar Pradesh; Environ. Earth Sci. 73 3655-3664, https://doi.org/10.1007/ s12665-014-3649-z.

Oladapo M I and Akintorinwa O J 2007 Hydrogeophysical study of Ogbese Southwestern, Nigeria; Global J. Pure Appl. Sci. 13(1) 55-61.

Oladapo M I, Mohammed M Z, Adeoye O O and Adetola B A 2004 Geoelectrical investigation of the Ondo State Housing Corporation Estate, Ijapo Akure, Southwestern Nigeria; J. Mining Geol. 40(1) 41-48.

Orellana E and Mooney H M 1966 Master tables and curves for vertical electrical sounding over layered structures; Interciencia, Madrid, Spain, 159p.

Pandey O P, Chandrakala K, Parthasarathy G and Reddy P R 2009 Upwarped high velocity mafic crust, subsurface tectonics and causes of intraplate Latur-Killari (M 6.2) and Koyna (M 6.3) earthquakes, India - A comparative study; J. Asian Earth Sci. 34 781-795. 
Rajesh R, Brindha K and Elango L 2015 Groundwater quality and its hydrochemical characteristics in a shallow weathered rock aquifer of southern India; Water Qual. Expo. Health 7 515-524, https://doi.org/10.1007/ s12403-015-0166-6.

Ramesh K and Elango L 2012 Groundwater quality and its suitability for domestic and agricultural use in Tondiar river basin, Tamil Nadu, India; Environ. Monit. Assess. 184 3887-3899. https://doi.org/10.1007/ s10661-011-2231-3.

Revil A and Leroy P 2001 Hydroelectric coupling in a clayey material; Geophys. Res. Lett. 28 1643-1646.

Salem H S 1999 Determination of fluid transmissivity and electric transverse resistance for shallow aquifers and deep reservoirs from surface and well-log electric measurements; Hydrol. Earth Syst. Sci. 3(3) 421427.

Shailaja G, Laxminarayana M, Patil J D, Erram V C, Suryawanshi R A and Gupta G 2016 Efficacy of anisotropic properties in groundwater exploration from geoelectric sounding over trap covered terrain; J. Ind. Geophys. Union 20(5) 453-461.

Shevnin V, Mousatov A, Ryjov A and Delgado-Rodríguez O 2007 Estimation of clay content in soil based on resistivity modeling and laboratory measurements; Geophys. Prospect. 55 265-275.

Singh C L and Singh S N 1970 Some geoelectrical investigations for potential groundwater in part of Azamgrah area of UP; Pure Appl. Geophys. 82 270285 .

Corresponding editor: Munukutla RADHAKRISHNA
Skordas K and Kelepertsis A 2005 Soil contamination by toxic metals in the cultivated region of Agia, Thessaly, Greece; Environ. Geol. 48 615-624, https://doi.org/10. 1007/s00254-005-1319-x.

Soil Survey Staff 1975 Soil taxonomy: A basic system of soil classification for making and interpreting soil surveys; U.S.D.A. Soil Conservation Service, Agri. Handbook No. 436, Washington DC, 754p.

Telford N W, Geldart L P, Sheriff R S and Keys D A 1990 Applied geophysics; Cambridge University Press, London.

Tiwari V M, Vyaghreswara Rao M B S and Mishra D C 2001 Density in homogenities beneath Deccan Volcanic Province, India as derived from gravity data; J. Geodyn. 31 1-17.

Tsepav M T, Adamu Y and Umar M A 2015 Evaluation of aquifer protective capacity and soil corrosivity using geoelectrical method; Int. J. Math. Comput. Phys. Electr. Comp. Eng. 9(11) 666-675.

Vasanthi A and Satish Kumar K 2016 Understanding conspicuous gravity low over the Koyna-Warna Seismogenic Region (Maharashtra, India) and Earthquake Nucleation: A paradigm shift; Pure Appl. Geophys. 173 19331948.

Zohdy A A R and Jackson D B 1969 Application of deep electrical soundings for groundwater exploration in Hawaii; Geophysics 34 584-600.

Zohdy A A R, Eaton G P and Mabey D R 1974 Application of surface geophysics to ground-water investigation; 2nd edn, United States Geological Survey, Reston, USA. 